\title{
Mycological discoveries in the Middle East region in the second part of the last century
}

\section{Mouchacca J}

Muséum National d'Histoire Naturelle, Département de Systématique et Evolution (UMR 7205), Case Postale no 39, 57 rue Cuvier, F-75231 Paris Cedex 05, France- mouch@mnhn.fr; jeanmouchacca@sfr.fr

Mouchacca J 2016 - Mycological discoveries in the Middle East region in the second part of the last century. Microbial Biosystems 1(1), 1-39

\begin{abstract}
The arid Middle East extends over 9 million $\mathrm{km}^{2}$ in the Eastern part of the Mediterranean Sea. Interest in the fungi of this region after the Second World War led to the discovery of species then regarded as being new to Science. A scan of the Index of Fungi issued in the period running from 1940-2000 revealed that 240 novel taxa had then been proposed. The recorded novelties were examined following the chronology of their introduction, their distribution in the local fifteen political states and their gross taxonomic characters at the Class level. These new additions were characterised at the rate of 40 units / decade. Most originated from Egypt, Iraq and the Palestine-Israel area and relate to the Classes Mitosporic Fungi, Ascomycetes and Basidiomycetes. All together 145 generic names are reported in this group of novelties; twelve were based on type material collected in Egypt (5 genera), the Palestine-Israel area, Iraq, Kuwait, Lebanon and Sudan. The present group of novelties was also surveyed in relation to the nature of the substrate sustaining the selected holotypes. The relevant Mitosporic fungi (93 taxa) were equally isolated from soil or from living or decaying plant parts. For Ascomycetous novelties (86 taxa), although their soil-borne elements outnumber the plant related ones, several also developed on other types of substrates. In the case of novel Basidiomycetes (37 taxa), the plantparasitic species encompass those collected on the ground surface. Finally, a limited number of these novelties disclosed notable thermotolerant abilities and some even qualify as thermophiles. The main features of these novel records underlines that in Egypt more attention was awarded to the local Mitosporic fungi and to Ascomycetes inhabiting its soil-borne communities. For the Basidiomycetes (sensu lato) marked interest developed solely in the Palestine-Israel area while in Iraq taxonomic studies focussed on Ascomycetes including those developing on dung substrates. The distribution of the few reported Chytridiomycetes, Zygomycetes and 'Oomycetes' also proved to be restricted to the former three states. Present data clearly underlines limited interest has been awarded to the fungi of a region presumed to harbour a specific mycobiota due to its marked arid features. Since 1940, only four novel taxa were thus proposed per annum from a small fraction of the Middle East. Future research should focus on plant related forms of lower (basal clades) and higher (Dikarya) fungi of the area. Conservation measures should also be adopted to ensure an adequate protection of the natural local habitats against the negative pressures generated by the increase in population and the detrimental effects of its activities. Finally, in view of the overwhelming implication of mycology in the fields of biotechnology, significant knowledge of the Middle East fungi is promising.
\end{abstract}

Key words - Ascomycetes - Basidiomycetes - novel taxa - thermophiles - thermotolerants 


\section{Introduction}

The Middle East region is part of the great North African Arabian desert belt extending eastward from the Atlantic Moroccan coast to the Indian subcontinent. Basically, it comprises the Arabian Peninsula and the land running north to the Turkish border. Egypt is usually integrated in this regional subdivision. Turkey and Iran are excluded from the present account due to its mountainous character. On the other hand, the inclusion of Libya and The Sudan (now limited to the north arid part) is preferred in the present delimitation of this region.

This concept of the Middle East correspond to an assemblage of fifteen political states having a total surface area of about 9 million $\mathrm{km}^{2}$, all characterized by an arid climate. In this vast land, agriculture is basically dependent on almost regular volumes of surface running waters originating, however, from sources situated outside the region, such as the River Nile.

The serious scientific study of this regional mycobiota can be traced back to 1813 , when Alire Raffeneau Delile provided in his 'Flora aegyptiacae illustratio, p. 33', and under the heading 'Ordo Fungi', a list of eight fungi among which only Phallus roseus Delile was new [now Itajahya rosea (A.R. Delile) Ed. Fisher]. A description of this famous gasteromycete was included in his 'Flore d'Egypte, avec explication des planches, p. 156, pl. 59'. Under the heading 'Ordo Lichenes', Delile (1813) also provided a list of twelve lichens, of which only two were already known (Seaward and Sipman 2006). Since then and up to the First World War, information about the fungi of this region stemmed mainly from collections made by European botanists during their exploratory travels in the area. Original specimens of taxa collected were then made available to mycologists established in Germany, France and Italy.

Notable interest in this regional fungal community became apparent after the First World War. The trend then related to organisms developing on native plants (Reichert 1921) or pathogenic to crops of economic importance (Melchers 1931). For soil-borne mycocoenoses, the pioneer work of Sabet $(1935,1939)$ on some Egyptian localities is now accepted as the starting point of research on these particular living communities. This exploration also led to the discovery of three novel taxa then described by the Dutch van Beyma in 1933 (van Beyma 1933 $\mathrm{a}, \mathrm{b}$ ). Their original strains are still maintained in the major living culture collection of the former Centraalbureau voor Schimmelcultures, Baarn (now at Utrecht since late 2000), The Netherlands. The nomenclature of these three taxa has, however, undergone some changes with time: two were transferred to other genera, the third proved to represent a later synonym (Mouchacca 1995).

The biological diversity of the fungi of the Middle East will certainly not be fully documented in the near future. Besides, no modern check-list of taxa reported for the region is yet available. Partial surveys of plant-pathogenic forms have been compiled in the past for a few local states (Waller et al. 2001), but these documents urgently require a thorough revision and updating. Some efforts were however recently made to account for the mycobiota of this arid zone (Mouchacca 1995).

The present contribution is a synthetic account on the fungi of the Middle East, regarded as being new to science at the date of their formal introduction along the investigated period. The resulting check-list has been updated with respect to the nomenclatural status and the taxonomic position of each new proposal. This document also attempts to analyse the correlations between the parameters depicting each fungal novelty; such includes the dates of introductions, localities of collection of the holotypes, taxonomic position of the collected fungus, and finally the type of substrates subtending the relevant holotypes.

This regional biodiversity document is intended to enhance our knowledge of, and stimulate research into, the mycology of this arid zone. 


\section{List of treated taxa}

The binomials of the Middle East novelties were extracted from the Index of Fungi. This twice a year publication started in 1940 as 'The Review of Applied Mycology', and appears regularly since. Every twenty parts represent one volume extending over ten years. For the present study, the first six volumes covering the period from 1940 to 2000 were thus scanned. For each novelty, the index provides the original bibliographic reference, the legal nomenclatural and taxonomic status and features of the type material including its locality of collection.

The nomenclatural position of the recorded novelties following the International Code of Nomenclature for Algae, Fungi and Plants (ICN; previously the International Code of Botanical Nomenclature) underlined, for the period under consideration, the invalid status of several names is commonly due to either the absence of a Latin diagnosis if the name was published after 1 January 1935 (Art. 36.1 ICBN), or the absence, after 1 January 1958, of the indication of the type specimen (Art. 37.1 ICBN). By comparison, fewer taxa are invalid due to Art. 37.5, i.e. indication of the type should be accompanied by the words 'typus' or 'holotypus'. Information on the selected type material (designated as holotype) and whenever possible of its location in a recognized fungarium (institution or collection) could be checked in Mouchacca (1995, 1999 and 2004), where the authorities and reasons behind taxonomic changes affecting the treated names are documented.

The present study basically considers the original names of introduction for the analyses of the correlations prevailing between the parameters depicting each novelty. This limitation was favoured in order to underline any single effort made to describe the local fungi in the period under consideration. Extensive search was however then undertaken in order to update individual nomenclatural and taxonomic positions, in case subsequent changes had occurred; these changes are reported in the attached 'Global List of Novelties Retrieved'.

Author(s) of cited fungal names are abbreviated following the recent electronic version

(www.indexfungorum.org) of Kirk and Ansell 'Authors of Fungal Names' (2003). The following abbreviations are introduced in the text: $f .=$ forma; var. $=$ variety; $f . s p .=$ forma specialis and subsp. $=$ subspecies.

\section{CHRONOLOGY of Introductions and Original Localities:}

Data collected indicates simply 247 new units had been proposed in the period extending from 1940-2000. These novelties comprise the seven elements belonging to the Classes Myxomycetes and Agonomycetales. In order to alleviate the discussion about the distribution of this group of fungi following the investigated parameters, these two minor taxonomic entities were not considered. The details of their seven units are however reported in the associated 'Global List of Novelties Retrieved'.

The distribution of the 240 novelties following the dates of introduction underlines a continuous descriptive activity prevailed all along the investigated period (Table 1). This body of new fungi was proposed at the low rate of 40 units / decade, with a peak of 52 names in the seventies. This rate of introduction appears, however, well below the mean during the first twenty years, a period succeeding the Second World War. It approximates this value in the next four decades. The overall trend is thus a gradual increase of the mean followed by a slight decline in the subsequent decades. A constant progress of this parameter with time has thus not occurred.

The second step focus on the distribution of the new units following the collecting sites of their holotypes (Table 1). Among the local fifteen states, four are not linked with any proposal: Bahrein, Qatar, United Arab Emirates and Yemen. Besides, the eleven providing states show a marked variation in their respective numbers of novelties; these range from the three Jordanian units to an optimum of 88 for the Palestine-Israel area (P-I area). The derived state contributions clearly underline a large part of their holotypes were collected in the P-I area, 
Egypt and less so in Iraq; indeed the total of their respective novelties amount to $72.4 \%$ of the group. The shares of the Syrian and Sudanese states although clearly less marked, supersede however those of the last six ones; the latter simply range from $1.2-3.8 \%$ respectively.

The next step is to examine the simultaneous distribution of these novelties following the two previous parameters (Table 1). Practically all units of the low providing states as Jordan, Libya, Oman and Saudi Arabia, were characterised after the sixties. The case of Kuwait is close to the former ones; its nine units were named either in the seventies or in the eighties: $5 \& 4$ taxa respectively, but no Kuwaiti proposal was made at the end of the last century. It is clear the new fungi of these four states are casual discoveries along the period under consideration.

Table 1 Distribution following political states and dates of introduction

\begin{tabular}{lccccccccc}
\hline \multicolumn{2}{l}{ State/Years 1940- } & $\mathbf{- 5 0}$ & $\mathbf{- 6 0}$ & $\mathbf{- 7 0}$ & $\mathbf{- 8 0}$ & $\mathbf{- 9 0}$ & $\mathbf{- 2 0 0 0}$ & TOTAL & $\mathbf{\%}$ \\
\hline JORDAN & JO & & & & 3 & & & 3 & 1.2 \\
LIBYA & LI & & & & 4 & & & 4 & 1.7 \\
OMAN & OM & & & & & & 4 & 4 & 1.7 \\
Saud.-Arab. & SA & & & & & 2 & 2 & 4 & 1.7 \\
LEBANON & LE & 6 & & & 1 & & & 7 & 2.5 \\
KUWAIT & KU & & & & 5 & 4 & & 9 & 3.8 \\
SYRIA & SY & 3 & & 13 & & & & 16 & 6.7 \\
The SUDAN & SU & & 6 & 2 & 4 & 5 & 2 & 19 & 7.9 \\
IRAQ & IR & 1 & & 4 & 3 & 7 & 18 & 33 & 13.7 \\
EGYPT & EG & & 1 & 10 & 24 & 15 & 3 & 53 & 22.0 \\
Pales.-Isra. & P-I & 17 & 16 & 20 & 8 & 9 & 18 & 88 & 36.7 \\
TOTAL & & 27 & 23 & 49 & 52 & 42 & 47 & 240 & 100 \\
$\%$ & & 11.3 & 9.6 & 20.4 & 21.7 & 17.5 & 19.6 & & \\
\hline
\end{tabular}

The Lebanese and Syrian states are noted by their proposals elaborated rather in the immediate post-war period: the first has six units in the forties and one Oomycete named in 1971; the second has three elements in the forties and curiously thirteen ones in the sixties. Finally for the Sudan, its 19 units were regularly and gradually defined over five decades starting from the fifties.

The three major contributing states also disclose dissimilar trends in the evolution of their proposals. Among the 33 Iraqi units, one single record relates to the forties but none was introduced in the fifties; its subsequent decade contributions are positive with a gradual increase to an optimum of 18 in the nineties. For Egypt (53 units), not a single name was proposed during the Second World War decade; its following introductions gradually increased however to a peak of 24 units in the seventies unfortunately followed by a slow decrease in the subsequent decades.

The P-I area is the sole case with positive introductions all along the investigated period. Its comparatively marked activity in the first two decades contrasts with the almost absence of similar trend in most other states. Nonetheless, its peak of twenty units of the sixties will slowly decrease in the next two decades before a slight increase in the nineties. This irregular trend is behind the record of 88 units of the P-I area.

\section{ORIGINAL Localities and Taxonomic Classes:}

When viewing the distribution of the novel fungi following their taxonomic characters, the Classes Ascomycetes and Mitosporic fungi appear the dominant ones: their respective marked relative weights represent $74.6 \%$ of all novelties (Table 2). The Class Basidiomycetes has a lower relative weight: $15.4 \%$, but this percentage is however equal to the total 
contributions of the three remaining classes: the Chytridiomycetes, the Oomycetes and the Zygomycetes.

The distribution of the elements of these Taxonomic Classes following their respective states of collection is also of interest (Table 2). Present data confirm the fungi of the three classes with limited contributions disclose exclusive links with the P-I area. Such is the case for the eight recorded Zygomycetes, for three Chytrids (its last unit is however from Egypt), and for ten out of the twelve named Oomycetes (its last two species are from Lebanon and from Iraq).

Table 2 Distribution following Taxonomic Groups and Political States

\begin{tabular}{lcccccccccccccc}
\hline $\begin{array}{l}\text { Taxonomic Groups } \\
\text { /Political States }\end{array}$ & & JO & SA & OM & LY & LE & KU & SY & SU & IR & EG & P-I & Total & \% \\
\hline Chytridiomycetes & Ch & & & & & & & & & & 1 & 3 & 4 & 1.7 \\
$\begin{array}{l}\text { Zygomycetes } \\
\text { Zy }\end{array}$ & & & & & & & & & & & 8 & 8 & 3.3 \\
Oomycetes & Oo & & & & & 1 & & & & 1 & & 10 & 12 & 5.0 \\
Basidiomycetes & $\mathrm{Ba}$ & & & & & & & 1 & 5 & 6 & & 25 & 37 & 15.4 \\
Ascomycetes & $\mathrm{As}$ & 1 & & 4 & 3 & 3 & 4 & 2 & 8 & 20 & 26 & 15 & 86 & 35.8 \\
Mitosporic fungi & $\mathrm{Mi}$ & 2 & 4 & & 1 & 3 & 5 & 13 & 6 & 6 & 26 & 27 & 93 & 38.8 \\
TOTAL & & 3 & 4 & 4 & 4 & 7 & 9 & 16 & 19 & 33 & 53 & 88 & 240 & 100 \\
\% & 1.2 & 1.7 & 1.7 & 1.7 & 2.9 & 3.8 & 6.7 & 7.9 & 13.7 & 22.0 & 36.7 & & \\
\hline
\end{tabular}

The Class Basidiomycetes has a general trend in line with that of the previous limited ones: two thirds of its novelties were collected in the P-I area. It deviates, however, by the absence of new species from Egypt, and the presence of few records from Syria, the Sudan, or Iraq. In addition, not a single novel Basidiomycete was reported from the six other political states.

The Class Ascomycetes is noted by its high contribution rate: $35.8 \%$, and by its presence in all states excepting Saudi Arabia. This Class is distinguished by a marked presence in Egypt and Iraq: 26 and 20 species respectively, but less so in the P-I area (15 spp.). On the contrary, limited numbers of Ascomycetes were discovered in the Sudan (8 spp.) or reported from the six other remaining states: 1-4 species respectively.

In terms of relative contributions, the 'Mitosporic fungi' appears as the dominant entity: $38.8 \%$ of all novelties. This Class is absent in Oman but is well represented in the P-I area and in Egypt: 27 \& 26 units respectively. In the other states, it groups 13 elements in Syria but less so in the remaining ones: from 1-6 species respectively.

\section{TAXONOMIC Classes and Holotypes Substrates:}

Three types of substrates supporting the holotypes of the present novelties could be defined: fungi developing on plant material whether living or not; soil substrate providing living cultures or supporting basidiocarps of higher fungi; and 'other types of substrates' as dung, insects, hair baits, African termites, etc. (Table 3).

Among the minor Classes, the relationship of the four Chytrids with plants is not exclusive since Rhizophydium racemosum A. Gaertn. 1954 originated from an Egyptian damp soil. The Zygomycetes records disclose strong affinities with other types of substrates excepting the soil-borne Actinomucor racemosum f. palaestina Rayss 1945. The named Oomycetes exhibit, on the contrary, a preferential link to plant material; the only exception is Calyptralegnia basraensis Muhsin 1994 isolated from a water sample of the Shatt Al-Arab River in Iraq. 
Table 3 Distribution following taxonomic classes, major contributing states and substrate types

\begin{tabular}{lcccccc}
\hline Taxonomic Groups/Substrate Types & No. Gen. & PLANT & SOIL & OTHERS & TOTAL & \% \\
\hline Chytridiomycetes & $(3)$ & 3 & 1 & & 4 & 1.7 \\
Zygomycetes & $(5)$ & & 1 & 7 & 8 & 3.3 \\
Oomycetes & $(4)$ & 11 & & 1 & 12 & 5.0 \\
Basidiomycetes & $(21)$ & 26 & 10 & 1 & 37 & 15.4 \\
Ascomycetes & $(59)$ & 26 & 36 & 24 & 86 & 35.8 \\
Mitosporic fungi & $(53)$ & 41 & 44 & 8 & 93 & 38.8 \\
\hline TOTAL & $(145)$ & 107 & 92 & 41 & 240 & \\
\hline SYRIA & & 3 & 13 & & 16 & 6.7 \\
The SUDAN & & 17 & 1 & 1 & 19 & 7.9 \\
IRAQ & & 16 & 8 & 9 & 33 & 13.7 \\
EGYPT & & 7 & 39 & 7 & 53 & 22.0 \\
Pal.-Israel & & 52 & 22 & 14 & 88 & 36.7 \\
TOTAL & & 105 & 83 & 31 & 209 & \\
\hline
\end{tabular}

Regarding the major Classes, a higher proportion of the named Basidiomycetes is connected with plant substrates as compared to those developing on the soil surface: 26 and 10 units each; in comparison, only Crepidotus variabilis var. stercorarius Reichert \& Aviz.-Hersh. 1959, was recorded on dung material. The reported Ascomycetes exhibit on the contrary a marked peak with the soil substrate, but their affinities with the remaining two substrates are almost similar: 26 units are linked with plants and 24 with other substrate types.

The last major Class of Mitosporic fungi has almost high and similar numbers of elements in both the plant or soil substrate types: 41 and 44 units respectively; in contrast simply eight of its species were collected on other types of substrates.

\section{Discussion}

The present information on the Middle East novelties clearly underlines simply four taxa were described each year all along the period from 1940-2000. This level of introduction appears insignificant with regard to the effective number of fungi new to science regularly described each year at the world level. Indeed over one thousand unknown species are presently named per annum: see The Index of Fungi. Needless to underline the relevant data featuring this arid region are rather alarming.

FIRST, the eastern part of the Mediterranean Sea received in the last century the attention of a panel of local and foreign mycologists. This action appears somewhat more effective in the case of Egypt, Iraq and the P-I area. Collected data confirm a fair proportion of the new fungi reported from this region during the investigated six decades were based on holotypes originating in these three states.

A scrutiny of the 27 novelties proposed in the forties of the last century underlines their author's names are mycologists that were active only in European laboratories or in the P-I area. Thus the six Lebanese units of this decade are due to F. Petrak of the Wien Natural History Museum: 3 ascomycetes and 2 mitosporic fungi developing on plant parts of Phlomis brevilabris collected by P. Bornmüller in the Near East in 1879. In the same decade, Petrak also introduced the mitosporic Ascochytella thymi 1941, found on Thymus syriacus in Iraq, and also due to the same Austrian botanist. 
The last Lebanese entry of the forties is the mitosporic Stegonsporium centaureae Rayss 1946, found on twigs of Centaurea dummulosa collected years ago by the botanist E. Eig in the Near East too. The Roumanian born T. Rayss has equally authored the three Syrian novelties of this decade. She arrived in the P-I area before the Second World War and her activities account for a fair number of local novelties.

In the fifties, T. Rayss and the similar Polish I. Reichert and other colleagues of the P-I area will also draft a number of new descriptions relating to this area. In the same decade, the Chytrid Rhizophydium racemosum A. Gaertn 1954 from Egypt, and few other names for the Sudan shall also be proposed by European experts.

The sixties will see the first proposals acted by local mycologists active outside the P-I area. For Egypt, the invalidly published Botrytis septospora El-Helali et al. 1962 is among the ten taxa then introduced by Egyptian and foreign experts for the Nile Valley. In this same decade, all the relevant Syrian units correspond to the twelve Penicillium species and Aspergillus kassunensis due to A.F. Baghdadi in the frame of his Russian thesis on the soil fungi of his country. However not a single name was then proposed from the other nine remaining states.

The seventies are marked by a peak of 52 novelties and, contrary to the former decade, their holotypes originated from a larger part of the Middle East extending over eight states. Half of these fungi concern Egypt and this production accounts for the relevant peak of new taxa then recorded for this country. The description of these Egyptian holotypes is however mostly due to the efforts of European experts; only Aspergillus egyptiacus and Ulocladium microsporum were then authored by local mycologists as A.H. Moubasher and A.F. Mustafa; Talaromyces assiutensis Samson \& Abdel-Fattah 1978, was then a collaborative project.

In the same seventies, the Jordanian, Libyan and Sudanese records are casual introductions due to foreign taxonomists. The similar five Kuwaiti names are a particular case as they were authored by the Egyptian A.F. Mustafa during his stay in the country. The related three Iraqi records represent the first attempts made by local experts and invited colleagues to elaborate new names. For the P-I area, on the reverse, a significant reduction in its proposals is evident: only eight species where then named as compared to the twenty units of the previous decade.

The eighties are noted by a decrease in the overall input: 42 taxa only. Here too, no new name relate to Jordan, Libya, Lebanon and Syria. The limited Sudanese records are still casual discoveries made by European experts. In contrast, the few Saudi Arabian and Kuwaiti taxa ( 2 \& 4 units each), are the first attempts of collaboration between local and invited colleagues. As for Iraq, its seven novel units were then either defined by local experts or in association with foreign colleagues.

In this same eighties Egypt is still the leading state before the P-I area, but with a serious drop in its input. Most of the Nile Valley new fungi are then due to the activity of A.F. Mustafa and his team of the Suez Canal University, Ismailia: ten out of the relevant fifteen new fungi were then characterised by this group. Finally the less marked input of the P-I area, is still in relation with the foreign experts newly established in this area.

The nineties exhibit a slight increase in the overall productivity due to the notable input from Iraq and the P-I area: 18 species each. The Iraqi proposals result from an active collaboration between the team of S.K. Abdullah with European experts, especially J. Guarro: 12 of the 18 Iraqi novelties are the outcome of this action. In the P-I area, the similar level of production is also due to European experts and young active local names. In this final decade, the Egyptian input has on the contrary slackened to a low level featuring the contributions of Oman, Saudi Arabia or the Sudan: 2-4 units each.

The novelties proposed during the investigated decades and the origin of the taxonomists associated with these fungi represent the guidelines of the corresponding mycological history of the Middle East. Expertise in the taxonomy of fungi was rather inexistent in the region at the 
beginning of the $20^{\text {th }}$ century. The First World War initiated an interest in these microorganisms due to a change in the overall political situation of the region. A number of foreign experts then either visited or spent some time in the Middle East to undertake research in relation with local problems of phytopathology. Permanent establishment of newcomers is most evident in the P-I area and this account for the new taxa then reported in the immediate post war decades.

Interest in the fungi of the Nile Valley did not however materialize immediately after World War II. It is only two decades later that the first local novelties were proposed by Egyptian or by foreign experts. Starting from the sixties the former developed a particular interest in the study of the soil-borne communities of the Nile Valley. This trend raised the problem of a sound identification of the isolated strains, a situation finally leading to the proposals of novel fungi commonly achieved outside of any international collaborative scheme. Unfortunately however, interest in this particular field of research declined at the end of the last century resulting in a severe reduction in the numbers of proposed novelties.

Mycology in Iraq will develop upon the return of S.K. Abdullah to his country. Several new fungi were then named at the turn of the last century most commonly as joint projects with foreign experts. Elsewhere in the region taxonomic mycology was not awarded any priority on the state research level or as an individual research theme.

This condensed account of the history of mycological discoveries in this region and of the features of the taxonomists behind this activity clearly underlines no particular relevant planned scheme of research had then prevailed. Joint projects need to be developed to ensure notable progress in our knowledge of this group of living organisms at the regional scale.

SECOND, the distribution of these Middle East fungi following their gross taxonomic features is also of interest (Table 2). The derived relative weights of the present six Taxonomic Classes appear clearly in line with the actual estimated figures of their known species numbers, as reported in the last Dictionary of The Fungi (Kirk et al. 2008). This correspondence accounts for the fact more novel Ascomycetes and Mitosporic fungi were then respectively observed in comparison to the remaining Classes. However, the Class Basidiomycetes seems on the contrary relatively low represented in terms of new fungi to what should be expected in theory.

Regarding the minor Taxonomic Classes, all the novel Zygomycetes simply originated from the P-I area. Of the four reported Chytrids, only the Egyptian Rhizophydium racemosum A. Gaertn., was observed outside this area. Besides, simply two out of the twelve Oomycetes had original localities outside the P-I area: Pythium orthogonon Ahrens from Lebanon, and Calyptralegnia basraensis Muhsin from Iraq.

The present arid region thus remains largely inexplored with respect to the elements of these minor Taxonomic Classes. An absence of interest in their representatives has apparently prevailed among local mycologists during the six surveyed decades. Alternatively, no foreign specialist developed similar interest for that region. However, Chytrids and Oomycetes and less so for Zygomycetes, are well known as parasites of plants and animals. These particular microorganisms are able to induce severe losses in some plant infection cases.

The novel described Basidiomycetes also disclose a distribution in favour of the P-I area: 25 out of their 37 reported names originate from this area. The former taxa correspond to an assemblage of eleven homobasidiomycetes of the genera Agaricus, Boletus, Crepidotus and five other generic entities; the fourteen remaining units are all heterobasidiomycetes: ten rusts of the genera Puccinia and Uromyces and four smuts of Entyloma and Ustilago. The last twelve non PI units of this Class are ten heterobasidiomycetes collected in Syria, the Sudan and Iraq, and two Iraqi species of the genera Galzinia and Hyphoderma.

The present distribution of the former basidiomycetes clearly underlines more rusts and smuts had been discovered in comparison to the corresponding Agarics sensu lato, despite the fact that the levels of novelties reported for either subclass appear rather limited. In addition not 
a single Basidiomycete whether homo- or hetero- was reported from the six others providing states of the region including Egypt.

The Middle East is noted by its limited winter rainfall and by its hot dry summer seasons, two global parameters unfavourable for the development of a rich homobasidiomycetous biota. These ecological constraints may account for the fact two thirds of the recorded units of this Class are heterobasidiomycetes. This limitation could also generate from an absence of local expertise in this major group of higher fungi. For Egypt, apparently no notable interest in either of the former subclasses has apparently prevailed in the sixty years under study. The native plants and the agricultural crops of the Nile Valley thus await to be documented for their associated spectra of plant pathogenic higher fungi.

The Class Ascomycetes has a marked relative weight: $35.8 \%$ of all names retrieved. It is represented in all providing states excepting Saudi Arabia. For Jordan, simply Coniochaeta nodulisporiodes D. Hawksw. 1978, is reported. In the case of Syria only Erysiphe communis $f$. fibigiae and Guignardia euphorbiae had been named by T. Rayss in 1946; both taxa are based on material previously collected by her in the Near East when it was then still possible to freely travel in this part of the Mediterranean. Four other states have records of either three (Libya and Lebanon) or four units (Oman \& Kuwait). Finally collections made in the last state, the Sudan, allowed the description of eight new fungi.

The former Class is however distinguished by a peak of novelties in Egypt (26 units) and a closer figure in Iraq (20 units); their Ascomycetes represent over half of the total records of this Class. It should be noted that for either state, foreign expertise (for Egypt), and marked collaborative efforts (for Iraq) encompass the input generated by local experts. For this same Class, the P-I area stands in a third position with only fifteen taxa having been proposed; over half of the latter are due to foreign experts and less so by local ones or via joint projects.

The final Class of Mitosporic fungi (probably all phylogenetically Ascomycetes) appears as the dominant entity based on its marked relative weight: $38.8 \%$. This Class is best represented in the P-I area and in Egypt; over half of its elements originate from both states: 27 and 26 taxa respectively. Syria here stands in a third position basically due to the twelve species of Penicillium and the single Aspergillus then reported by A.F. Baghdadi.

No Mitosporic fungi was however reported from Oman while for Libya simply Nematoctonus tripolitanius Giuma \& R.C. Cooke 1972, had been described. For Jordan, the sole relevant taxa are Cylindrotrichum gorii Lunghini, 1979 and Humicola hyalothermophila Moub. et al. 1979, a thermophilic fungus. The remaining four states have minor contributions simply ranging from three (Lebanon), four (Saudi Arabia), five (Kuwait) or six novelties (the Sudan and Iraq).

A scrutiny of the author's names of the novel Mitosporic fungi stress over half (56.9\%) was named by local experts active in the P-I area or in Egypt; this observation is not in line with that of the Class Ascomycetes where most proposals were generated by foreign mycologists. The input of Mitosporic fungi by foreign colleagues is less marked (37.7\%), while that of the joint descriptions appears very limited (5.37\%). Indeed the relevant 27 P-I protologues were drafted by a panel of local experts, particularly T. Rayss, and by an array of foreign ones as E.G. Simmons, P.F. Cannon, Sage et al., etc. The similar 26 Egyptian taxa were equally described by local colleagues as A.H. Moubasher, A.F. Mustafa and Abdel-Wahid, and several foreign ones as W. Gams, J. Mouchacca and R. Samson and again E.G. Simmons. It is clear local taxonomists in the P-I area and in Egypt were able to achieve by themselves the characterisation of the novel Mitosporic fungi they encountered.

The above analysis clearly underlines many actors have participated in the characterization of the present group of Middle East novelties following their individual expertise in one or the other of the represented Taxonomic Classes. The share of the foreign taxonomists is evident in the introduction of the new names collected either as an independent 
achievement or via collaborative schemes. A sound increase in our knowledge of this regional mycobiota is evidently not a simple file.

THIRD, the distribution of these regional novelties following the nature of their holotype substrates could also be examined. The three plant related Chytrids developed on living leaves in the P-I area; these species of Synchytrium and Urophlyctis are due to T. Rayss in the forties. The similar eleven Oomycetes were introduced as species of Peronospora and Sclerophthora then collected on living leaves of local and standing crops in the same area; these were also named by T. Rayss but in the sixties.

The seven Zygomycetes of the 'other substrates' are associated with a panel of insects and an apothecia of a fungus, all again gathered in the P-I area. These members of the genera Adlerocystis, Entomophthora, Zoophthora and Rhopalomyces were characterized by several local experts including T. Rayss. However, their respective taxonomic status apparently needs to be re-assessed.

The general observations depicting the former three minor Taxonomic Classes add weight to the earlier statement about the distribution of their elements being confined to the P-I area. However as the numbers of their respective proposals appear rather limited, more research is therefore needed for a better knowledge of the real populations of Chytrids, Oomycetes and Zygomycetes inhabiting the Middle East region.

Regarding the remaining three Classes, the reported Basidiomycetes display a preferential link with the 'plant subgroup': 26 out of its 37 novelties inhabited living wild or cultivated plants. These records relate to the subclass Heterobasidiomycetes with two exceptions: the Iraqi Galzinia cystidiata S.S. Rattan \& Abdullah 1976, found on decomposing wood, and Hyphoderma puberum var. dactyliferum S.S. Rattan \& Al-Dboon 1980, a common white rot of date palms. These 24 plant parasitic fungi are affiliated to eleven genera: Uromyces has apparently received a particular attention as ten units had been added to the genus; Entyloma and Puccinia comprise three units each, and for the eight remaining genera a single respective species was reported.

The original localities of the former heterobasidiomycetes are mostly situated in the P-I area (14 units), less so in either the Sudan or Iraq ( $5 \& 4$ units respectively), or in Syria where only Tilletia sphenopodi T. Rayss 1946, had been collected. The protologues of the 14 P-I taxa were also drafted by T. Rayss and by her colleagues recently established in this area. The similar Iraqi units are, however, due to Z. Urban and those of the Sudan to few European experts.

The Homobasidiomycetes of the 'soil subgroup' are ten species of the following genera: Agaricus (4 species), and for Boletus, Lepista, Macowanites, Russula, Scleroderma and Tricholoma only a single unit was then proposed. Interestingly again, their selected holotypes were also simply collected in the P-I area. It is clear the whole Middle East remains yet almost unexplored for the biodiversity of this major group of higher fungi. Finally, for the same Class Basidiomycetes, the remaining 'other subgroup' simply includes Crepidotus variabilis var. stercorarius Reichert \& Aviz.Hersh. 1959, found on dung material and again in the P-I area.

The former distribution of the novel heterobasidiomycetes suggest not a single plant parasitic fungi had been observed in the other providing states of the region and, most particularly, in the fertile Nile Valley. Also apparently no partial or total local monographic project focusing on this particular fungal group had been planned in the period under examination.

The Class Ascomycetes, on the contrary, discloses a marked peak for its soil related species: 36 units could then be named from the corresponding isolated living cultures. Among these units, twenty concern the Nile Valley. Although only part of the latter is due to the activity of local experts, such a notable level of proposals is an indirect proof of the marked interest then awarded for the exploration of the Egyptian soil-borne communities; this trend is presently 
however on the decline. The last sixteen soil Ascomycetes display a wide geographical distribution: P-I area and Iraq (5 units each), Kuwait (3 units) and a single unit for each Jordan, Oman and the Sudan.

The same Class Ascomycetes is also noted by a comparatively lower but rather equal species numbers for its two other subgroups. The 26 plant related forms include the first novelties from Iraq: eight species were then proposed. The other 18 ones partly relate to the Sudan and the P-I area: $6 \& 5$ units respectively, and less so to Lebanon or Syria ( $3 \& 2$ units each); the last two units of this 'plant subgroup' were collected in Egypt, an information in contrast with the previous twenty records of the Egyptian 'soil subgroup' units.

The Ascomycetes of the others substrates ( 24 units) are remarkable by their 17 elements isolated from dung. These particular fungi include the first proposals from Oman and Libya: 3 and 2 taxa respectively; the remaining dung fungi are linked to Iraq ( 7 units), Egypt ( 3 units) and the P-I area: 2 units. In contrast, the last seven elements of this same subgroup are associated with an array of material as marine sludge (Egypt), termites and insects (Libya and the Sudan), a water sample from the Dead Sea or an algae in the P-I area.

The final Class of Mitosporic fungi is noted by its high record of 93 novelties. It also has almost equal and marked figures for either the 'plant subgroup' or the soil related records: $41 \&$ 44 cases respectively; on the contrary, its 'other substrates' subgroup simply includes eight names.

The 44 soil Mitosporic fungi have original localities extending over seven states. Here, the Egyptian and Syrian cases are well provided: $18 \& 13$ records respectively. The proposal of these Egyptian taxa adds weight to the statement about the particular interest developed in the Nile Valley for its soil communities. The thirteen Syrian names correspond to the twelve Penicillia and the single Aspergillus named by A.F. Baghdadi from his country; however, no subsequent fungus was later on authored by him. The last thirteen soil units were issued from the P-I area (6 units), Iraq (3 units), Kuwait (2 units) or from Jordan and Saudi Arabia: one species each.

These 44 Mitosporic soil units are linked to a large panel of 24 genera. In addition to the Syrian Penicillia, six novel Aspergilli were then introduced from the P-I area or from Egypt: 3 units each. The following genera Cladorrhinum, Exserohilum, Gilmaniella and Ulocladium are each represented by two units while for the remaining 18 ones only a single species was then proposed. No particular survey has apparently been undertaken in the region about the distribution of the local Mitosporic fungi.

The almost equivalent well provided 'plant subgroup' of this Class is rather characterized by the marked input of the P-I area: 20 units out of its 41 names relate to this area. Its last 21 species have original localities in seven different states: six were respectively discovered in Egypt and in the Sudan, and three others from Lebanon; the last Mitosporic species are two elements from each Saudi Arabia and Iraq, and a single one from either Kuwait or Jordan.

The former Mitosporic 'plant subgroup' is also noted by the diversity of the affiliated genera: 27 names. The best represented ones are Cercospora (5 units), Septoria (4 units), Alternaria and Penicillum (3 units each), and finally Exserohilum, Oidium and Stigmina: 2 species each. These genera are well noted for their impact as plant parasites. For the remaining twenty genera, only one taxon was reported for each. No specific Mitosporic genus has apparently been surveyed on the regional or local scale.

The last Mitosporic elements of the 'other substrates' are simply eight taxa connected to six states. Their original localities are in Egypt and Kuwait (2 units respectively), or in Libya, Saudi Arabia, Iraq and the P-I area. These eight units were extracted from a diversity of uncommon substrates as the intestine of a larva of Prodenia litura (Aspergillus flaschentraegeri Stolk 1965), hair baits immersed in horse dung, air borne spores or from a soil nematode. 
The present analysis of the relationships between fungal novelties and substrate types stress a wide diversity of the latter had been explored for their content of living fungi with somewhat promising results about the biodiversity of these living organisms. The pioneer fungal studies then undertaken and particularly of the soil-borne communities has however slackened at the end of the last century and apparently has not gained in intensity since. More emphasis should be promoted to ensure the development of our knowledge about the parasitic and saprophytic elements of this regional mycobiota.

FOURTH, the distribution of the same novelties following the state of origin and the nature of their holotype substrates is also of interest. In order to extract the major guidelines of this correlation, the states providing less than $5 \%$ of all novelties shall not be considered (Table 3).

For Syria, its 'soil subgroup' units are the thirteen species defined by A.F. Baghdadi. Its 'plant subgroup' forms are the Ascomycetes Erysiphe communis f. fibigiae and Guignardia euphorbiae, and the Smut Tilletia sphenopodis, all due to T. Rayss in 1946. For this state too, not a single fungus of the 'others subgroup' types has been reported. It follows more remains to be accomplished for this wide country of the Middle East.

For the Sudan (19 units), Stigmatomyces ligabuei W. Rossi 1984, a parasite of fly insects, is the single record of the 'others subgroup' types. Also, Pseudophaeotrichum sudanense Aue et al. 1969, involved in human diseases, appears as the only element isolated from soil. It follows the 17 other Sudanese taxa are plant related forms: six Ascomycetes, six Mitosporic fungi and five heterobasidiomycetes; the last ones are due to foreign experts as Laundon, Ling, Spooner, Tarr \& Vanky. The Ascomycetes were also described by European mycologists or as a joint project as Setosphaeria khartoumensis El Shafie \& Webster 1981. Such is also the case for the final six Mitosporic names excepting Drechslera gedarefensis El-Shafie 1980. It follows that apparently no local taxonomist was active in the country during the investigated period; besides its novel fungi rather correspond to casual collections made by visiting botanists.

The Iraqi novelties, though more numerous in comparison to the former state (33 units), has, however, a 'plant subgroup' almost equivalent in weight. Here, the nine 'other subgroup' includes the Oomycete Calytralegnia basraensis Muhsin 1994, and the Mitosporic Stachybotrys guttulispora Muhsin \& El-Helfi 1981. Interestingly, the remaining seven Ascomycetes of this subgroup originated from dung and belong to the genera Corynascella, Iodophanus, Podospora, Preussia ( $3 \mathrm{spp}$.) and Strattonia: their protologues were drafted by Iraqi mycologists led by S.K. Abdullah and with the collaboration of J. Guarro.

The eight Iraqi elements of the 'soil subgroup' are five Ascomycetes of the genera Chaetomium (2 species), Emericella, Coniochaetidium and Thielavia; their diagnoses are also due to the joint efforts of local and foreign experts. The relevant three soil Mitosporic taxa are Stanjemonium fuscescens, Thermophymatospora fibuligera, and Trichurus dendrocephalus; these were similarly documented by local taxonomists in association with W. Gams, S.I. Udagawa and Y. Horie.

The notable third Iraqi 'plant subgroup' (16 units) also includes eight Ascomycetes of the genera Arxiomyces, Monascus (2 species), Preussia, Sphaerodes, Syspastospora and Zopfiella (2 spp.); these were described with the assistance of European experts as P.F. Cannon. This subgroup also includes two homobasidiomycetes: Galzinia cystidiata Rattan \& Abdullah 1976, and Hyphoderma puberum var. dactylifera Rattan \& Al-Dboon 1980, and four heterobasidiomycetes of the genera Aecidium, Puccinia, Uredo and Uromyces, all named by Z. Urban. The last plant related forms are the Mitosporic Ascochytella thymi Petrak 1941 and Exserohilum curvispora Sivan. et al. 1993.

For Iraq, it is thus evident a notable collaboration occurred between its mycologists and foreign ones all along the final thirty years of the last century. This has largely contributed to our 
knowledge of the Mesopotamian mycobiota, in particular of its ascomycetous component developing on dung substrates.

In the case of Egypt, the distribution of its novelties is well in favour of the "soil subgroup': 39 units, against seven for the plant and others subgroups respectively. The 'others subgroup' simply has five Ascomycetes and two Mitosporic fungi: the first are three dung related species of Arnium, Podospora and Zygopleurage described by N. Lundqvist, and two others from marine sludge authored by Japanese experts: Eupenicillium egyptiacum and Thermoascus egyptiacus. It's last two Mitosporic taxa are Aspergillus flaschentraegeri Stolk 1964, from the intestine of a larva of Prodenia litura and apparently not recorded since and Trichosporon pharaonis Maged et al. 1992, an air-borne fungus from a Pharaonic tomb.

The Egyptian 'plant subgroup' simply includes an Ascomycete found on a moss plant in Cairo: Octospora tetraspora J. Moravec 1972, and six Mitosporic fungi. The latter were named partly by local mycologists as the invalid species of the genera Botrytis, Cephalosporium, Geotrichum and Macrosporium, or by foreign ones as the valid Exserohilum oryzinum and Penicillium allii.

The marked Egyptian 'soil subgroup' (39 units) comprises the single Chytrid of the Nile Valley: Rhizophydium racemosum A. Gaertn.; it also has a fair number of Ascomycetes and Mitosporic fungi. The twenty soil Ascomycetes belong to 13 genera: Chaetomium and Thielavia are each represented by four and Emericella by two species; for the ten other genera only a single taxon was named. These Ascomycetes were authored by an array of local and foreign experts. The local ones are behind the pioneer Chaetomium mareoticum Besada \& Yusef 1968, succeeded by Chaetomiopsis dinae, Chaetomium sinaiense, Lasiobolidium aegyptiacum and Thielavia egyptiaca, all due to A. F. Mustafa and his colleagues.

The bulk of the same 'soil subgroup' is due however to the exclusive activity of Canadian (Gelasinospora hippopotami Krug et al. 1994) and European taxonomists. Indeed several of its elements were described by R.A. Samson and J. Mouchacca (Emericella desertorum, E. purpurea, Eurotium xerophilum and Rhexothecium globosum), or by the latter alone: Ascobolus egyptiacus, Podospora faurelii, Pseudoeurotium desertorum and three species of Thielavia. Talaromyces assiutensis Samson \& Abdel-Fattah 1978 is here the sole case involving local and foreign expertise.

The history of the novelties originating from the Nile Valley clearly underlines no species of the Taxonomic Classes Zygomycota and 'Oomycetes', had been proposed from this land in the investigated period. The same conclusion applies for the Class Basidiomycota which includes the notable plant parasitic forms, the rusts and the smuts. Finally and contrary to the Iraqi case, practically no collaborative links were formally established between local experts and those active elsewhere.

The similar distribution of the P-I fungi stress the 'plant subgroup' is, on the contrary, the dominant one: almost $60 \%$ of its new taxa belong to this subgroup. The figures for the soil records or for the 'other subgroup' types are definitely less marked.

The 14 elements the 'other subgroup' exceptionally relate to four taxonomic classes. Thus all the seven P-I Zygomycetes were not observed on plants or inhabited the soil. They rather developed on insect hosts and placed in the genera Adlerocystis (a present nom. inval.), Entomophthora or Zoophthora: 2 species each; the last Rhopalomyces elegans $f$. minor developed on the apothecia of a fungus and is also an invalid name.

The second seven units of this subgroup are five ascomycetes observed on various substrata: dung for Chaetomium dreyfussii and Saccobolus kerverni $f$. minor, Citrus peel juice for Clavispora lusitaniae, Dead Sea water for Gymnascella marismortuis, and finally an algae for Pleospora gracilariae; its last two units are the homobasidiomycete Crepidotus variabilis var. stercorarius, also reported from dung, and the hyphomycete Pseudomicrodochium fusarioides 
isolated from the bronchial lavage fluid of a Homo sapiens. This exceptional array of substrates types is uncommonly investigated in general.

The P-I 'soil subgroup' members are similarly linked to four classes due to the presence of Actinomucor corymbosus f. palaestina, the only novel Middle East Zygomycete isolated from soil; it is now however regarded as a superfluous distinction of the species. The other three Classes groups five Ascomycetes, six Mitosporic fungi and ten Basidiomycetes. The five soil Ascomycetes relate to the genera Microascus, Pulvinula and Thielavia; the taxonomic status of few await re-evaluation: see the associated General List. The six soil Mitosporic fungi are three valid taxa: Bipolaris israeli, Exserohilum israelii and E. sodomii, and three invalid ones: two Aspergillus and Periconia pycnospora f. israelitica.

The ten Basidiomycetes of the former 'soil subgroup' were observed on the soil surface: three Agaricus (A. bonii, A. herinkii, and A. nevoi), Boletus reichertii, Macowanites galileënsis, Russula carmelensis, Scleroderma multiloculare and Tricholoma weizianum. The associated two varieties proposed for Agaricus meleagris and Lepista sordida have not, apparently, not gained wide acceptance.

For the same P-I area, the 'plant subgroup' is however the most important one: 52 novelties, a figure exceeding the total of the 'plant subgroup' records of the former four states. The P-I plant fungi relate to all the taxonomic classes excepting the Zygomycota; the novelties of the latter proved to belong to the former P-I 'other subgroup'. These plant forms are a mixture of three Chytrids, almost all Oomycetous taxa, five Ascomycetes, fourteen Basidiomycetes and finally twenty Mitosporic fungi.

The three P-I Chytrids of the genera Synchytrium and Urophlyctis, had infected the leaves of Astoma sessifolium and Eryngium creticum. The P-I Oomycetes are eight valid or invalid Peronospora and two valid species of Sclerophthora; all grew on living leaves of local native plants or on those of standing crops. The relevant five Ascomycetes are two serious pathogens, Caenothyrium citri Reichert \& Chorin agent of a sooty blotch disease of Citrus plants, and Polystigma amygdalinum P.F. Cannon, a serious pathogen of local almond trees; also present are Chaetomium oblatum Dreyfuss et al., deriving from unknown seeds, Leptosphaeria pimpinellae Lowen \& Sivan., growing on dead stems, and the invalid Spaherulina serograpta var. calliprini Rayss, collected on living leaves of Quercus calliprinos.

The fourteen heterobasidiomycetes of the P-I 'plant subgroup' are all plant parasitic forms of the genera Uromyces (8 spp.), Entyloma (3 spp.), Puccinia (2 spp.) and Ustilago jehudana Zundel. The final twenty P-I Mitosporic fungi of the same subgroup are attached to several genera: some are reported as plant pathogens as the four species of Septoria, the three ones of Cercospora, and the two records of either Alternaria and Oidium; the remaining cited genera are however simply regarded as weak parasites: Cercosporina, Cytosporium, Diplodia, Fusariella, Penicillium (2 spp.), Phyllosticta or Stemphylium.

The P-I area thus appears an exclusive case due to the presence of a fair number of Basidiomycetes; these are either homo- and then relate to the 'soil subgroup', or hetero- and are then in connection with the 'plant subgroup'. This major Taxonomic Class is either absent or has a limited presence in most other states. Besides although the weight of the P-I Mitosporic fungi appears equivalent to their relative importance in Egypt, the P-I assemblage discloses less ascomycetous taxa in comparison.

The former analysis underlines which specific group of fungi of the present Middle East region has been preferentially explored particularly in the P-I area, Egypt or Iraq. It also stress which habitat was concerned in each state and the actors behind the novelties proposed. This survey also brings to light the contribution of the local taxonomists, the respective efforts of those active in foreign countries and the eventual association of both groups of individuals. 
FIFTH, among the 145 genera relating to the recorded novelties (see Global List of Novelties Retrieved), twelve were proposed to accommodate material collected in the Middle East. These new genera include the pioneer Lebanese ascomycetous Neobroomella and Thryptospora, still valid nowadays. Both were described by Petrak in 1947 from dead stems of Phlomis brevilabris collected in the Near East by the botanist J. Bornmüller in 1897 and then deposited at the Vienna Natural History Museum (Table 4).

Table 4 Novel genera reported from the Middle East in the period from 1940-2000

\begin{tabular}{cll}
\hline Year & \multicolumn{1}{c}{ Taxa } & \multicolumn{1}{c}{ Information } \\
\hline 1947 & Neobroomella ciliata Petrak & Lebanon, Ascomycete \\
1947 & Thryptospora singularis Petrak & \\
1963 & Adlerocystis parkeri Feld.-Mushs. \& Havivi & P-I area, Zygomycete \\
1969 & Pseudophaeotrichum sudanense Aue et al. & The Sudan, Ascomycete \\
1975 & Rhexothecium globosum Samson \& Mouch. & Egypt, Ascomycete \\
1976 & Desertella globulifera Mouch. & Egypt, Mitosporic fungi \\
1976 & Hyalocladium moubasherii Mustafa & Kuwait \\
1979 & Clavispora lusitaniae Rod. De Miranda & P-I area, Ascomycete \\
1986 & Thermophymatospora fibuligera Udagawa et al. & Iraq, Mitosporic fungi \\
1989 & Setosporella mahmoudii Mustafa \& Abdel-Wahid & Egypt \\
1990 & Mucobasispora tarikii Mustafa \& Abdel-Wahid & Egypt \\
1990 & Chaetomiopsis dinae Mustafa \& Abdel-Wahid & Egypt, Ascomycete \\
\hline
\end{tabular}

Two other new genera relate to the P-I area. The early Adlerocystis Feld.-Muhs. \& Havivi: type species A. parkeri Feld.-Muhs. \& Havivi, is a yeast-like zygomycetous fungus, probably a symbiote of sperm cells of the female ticks Ornithodoros parkeri; it is now considered as being invalidly published (Art. 39.1 Melbourne). The second is the yeast heterothallic ascomycetous genus Clavispora Rodr.-Pir.; its mitosporic mating strains, two species of Candida Berkhout, were isolated from Citrus peel juice in this area.

Five genera were reported from Egyptian soils. Their type species are the Ascomycetes Rhexothecium globosum and Chaetomiopsis dinae, and the Mitosporic Desertella globulifera, Setosporella mahmoudii and Mucobasispora tarikii. Three were authored by local experts as A.F. Mustafa \& Abdel-Wahid; the two others are due to European ones. The type strain of Desertella globulifera Mouch. originated from soil collected in the Depression of Khargah, Western Desert of the country.

The last five novel genera have original localities in the Sudan, Kuwait and Iraq. Pseudophaeotrichum sudanense Aue et al. was first isolated from severe human white-grained mycetomas in the Sudan; it was then reported from other African countries, particularly from Senegal, and also in Australia. The exact taxonomic position of this type species is still a matter of debate. The air-borne Kuwaiti Hyalocladium moubasheri Mustafa was dedicated to Prof. A.H. Moubasher, Assiut University; this hyphomycete develops morphological features close to members of the dematiaceous genus Ulocladium Preuss, but lacks, however, the presence of melanin in its hyphal wall.

The soil hyphomycete Thermophymatospora fibuligera originated from an Iraqi date palm plantation and then regarded as a thermotolerant fungus. Its description is the outcome of a joint project between S.K. Abdullah and both S.-I. Udagawa and T. Awao. The type strain was noted by the presence of clamp connections at the transverse septa. The fungus had a growth temperature range from 17-48, with an optimum at 35-40 and no growth at $50{ }^{\circ} \mathrm{C}$; these data qualifies for the status of a thermotolerant fungus sensu Cooney \& Emerson (1964). 
This thermotolerant Iraqi fungus was subsequently recorded in Japan from Nagura River and Maria River (Ito and Nakagiri 1979). Later on, Adskavege and Gilberston (1989) noted the presence of 'chlamydospores' in the cultures of the basidiomycete Ganoderma colossus (Fr.) C.F. Baker; these proved to be similar in morphology to the 'conidia' of the Iraqi strain. The current name of this Ganoderma is Tomophagus colossus (Fr.) Murrill. Later on Adskavege \& Gilberston (1989) indicated their Ganoderma isolates had a growth range from $25-48^{\circ} \mathrm{C}$ and a temperature optimum from $35-40{ }^{\circ} \mathrm{C}$. The latter range is identical to the one noted by the original describing authors but a growth range values of $25-48^{\circ} \mathrm{C}$ would qualify the fungus rather as a thermophile.

Further research on the fungi of the region should undoubtedly result in the discovery of other genera new to Science.

SIXTH, a scrutiny of the growth temperatures values provided for a number of the Middle East novelties, confirm several could be qualified as thermotolerants or even as thermophiles, following the relevant definitions provided by Cooney and Emerson (1964).

Twenty-four of the present novel fungi could be regarded as being thermophiles (4 species) or as thermotolerants (Table 5). Recent taxonomic and ecological information on known thermophilous fungi were recently provided by Mouchacca in a series of papers (1997, 1999, $2001 \& 2007)$. Actually, about fifty taxa could be regarded as strict thermophiles. It follows the present Middle East elements complying with the definition of a thermophile represent $12.5 \%$ of accepted members of this thermic subgroup.

The thermophilic Iraqi Chaetomium mesopotamicum Abdullah \& Zora has apparently not been reported again; according to Sriakshmi et al. (2015), it is a good producer of thermostable proteases as potential sources for leather processing along with bacterial proteases in India. The similar Thielavia minuta var. thermophila Abdullah \& Al-Bader, originated from a forest soil: because of some differences between its original strain and the parent species Thielavia minuta (Cain) Malloch \& Cain, the Iraqi authors regarded their isolate as a new variety of the latter. A subsequent comparison of both holotypes revealed however they are quite different and both of unclear taxonomic position: the two taxa vary in the morphology of their ascospores, the type of their peridium and the thermophilic and mesophilic nature of their living isolates. This accounts for the transfer of the variety to the genus Melanocarpus Arx (Guarro et al. 1996).

Thermoascus aegyptiacus S. Ueda \& Udagawa was encountered during the analysis of a sample of marine sludge collected along the Suez Canal banks at Port Saïd City; it was later on reported to inhabit Iraqi soil by Abdullah and Al-Bader (1990). This Ascomycete was then transferred to Coonemeria Mouch. (Mouchacca 1997) to account for the presence of cleistothecial ascomata having coiled ascogonial initials, pseudoparechymatous walls of textura angularis type and a Paecilomyces anamorph.

The last thermophile Humicola hyalothermophila Moubasher et al., is a soil fungus inhabiting cultivated lands in Jordan. It was distinguished from the mesophilic Humicola fuscoatra Traaen mainly by its slightly larger hyaline conidia and intercalary chlamydospores (Moubasher 1993). This Humicola was also observed in Saudi Arabian soils (Bokhary 1986). As underlined by Mouchacca (1997), the taxonomic position of this thermophile needs to be reassessed.

Besides the former, twenty novelties of the Middle East qualify as thermotolerants; this thermic subgroup is composed of thirteen ascomycetes, six mitosporic fungi and Thermophymatospora fibuligera, the anamorph of Ganoderma colossus. Surprisingly all these thermotolerants (and also all previous thermophiles) were simply isolated from soils of different types. 
Table 5 Novel thermophilic, thermotolerant and xerotolerant fungi reported from the Middle East

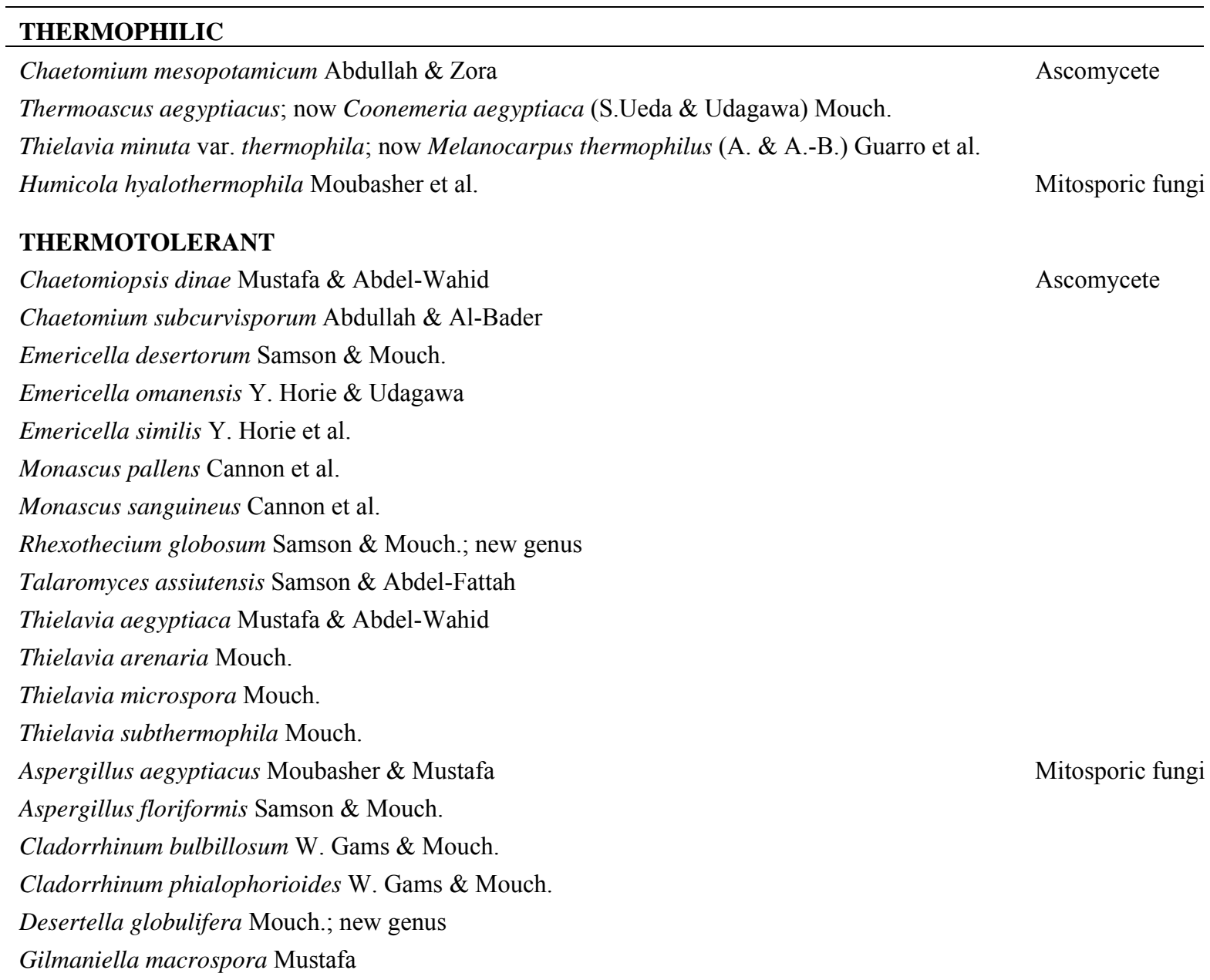

Thermophymatospora finuligera Udagawa et al.; new genus

XEROTOLERANT

Eurotium xerophilicum Samson \& Mouch.

Ascomycete

The thermotolerant ascomycetes belong to seven genera: Thielavia, Emericella, and Monascus are represented by more than one species; for Chaetomiopsis Mustafa \& AbdelWahid, Chaetomium Kunze and Rhexothecium Samson \& Mouch., only one novel taxon was introduced for each. Chaetomiopsis dinae and Chaetomium subcurvisporum are distinguished by ostiolate ascocarps. Thermotolerant elements of the genera Thielavia, Emericella, Monascus, Rhexothecium and Talaromyces have closed ascocarps. It follows arid regions seem to be a good reservoir for the discovery of new cleistothecial ascomycetes able to develop at high temperatures.

Chaetomiopsis dinae original habitat is an Egyptian agricultural soil and has apparently not been reported again. Chaetomium subcurvisporum was first isolated from an Iraqi forest soil and was then recovered from surface sediments of the Shatt Al-Arab River (Abdullah and Abbas 2008). The thermotolerants species of Thielavia also inhabit Egyptian soils: cultivated land in the Delta for T. aegyptiaca, sand dunes in the Western Desert of Khargah depression for $T$. microspora and T. arenaria, and a grey soil in the same locality for T. subthermophila. The latter was recently involved in the first case of a fatal brain infection of an Indian farmer (Badali et al. 
2011). This succeeds a previous case of keratitis in a 10-year old girl induced by the same (Theoulakis et al. 2009).

The three thermotolerant soil-borne Emericella were reported from Egypt, Oman and Iraq. E. desertorum was thoroughly investigated by Japanese chemists for the production of new molecules; together with Silvaticol, Nidulol, Ergosterol, Paxilline and Mannitol, three new Bicoumarins designated as Desertorin A (1), B (2) and C (3) could be extracted using the type strain CBS 653.73 (Nozawa et al. 1987). The distribution of E. omanensis and E. similis await to be documented.

The soil-borne Iraqi Monascus pallens and M. sanguineus were re-observed by Abdullah and Abbas (2008) in surface sediments of the Shatt Al-Arab River. According to these authors, the majority of Monascus taxa have been considered to be typical of osmophilic habitats being frequently isolated from foodstuffs or other substrates with low water activity. It follows the presence of these two distinct members in the surface sediment of a river is rather surprising. Elements of this genus are well known for their fermented products, especially red mould rice, a traditional fermented food in East Asian areas with a very long edible history.

The seven heat tolerant hyphomycetes include Aspergillus egyptiacus (Moubasher and Mustafa 1972), the first Egyptian novel taxon assessed by Moubasher and his colleagues. It was recently renamed Emericella egyptiaca (Moub. \& Mustafa) Pitt \& J. Taylor, based on retypification of the genus Aspergillus with A. niger as type species [see Pitt and Taylor, Mycologia, 106: 1051-1062, 2014]. However no teleomorph has yet developed in its representative strains. This Aspergillus was redescribed by Samson and Mouchacca (1974) from soils of the Khargah depression and its thermic features were then assessed: optimal growth at $45^{\circ} \mathrm{C}$, minimum at $15^{\circ} \mathrm{C}$ and maximum at $45^{\circ} \mathrm{C}$. This Aspergillus is also strongly osmophilic growing even on Czapek agar with $70 \%$ sucrose and such accounts for its isolation from a hypersaline beach sand in Israel (Subramanian and Wasser 2001).

The second relevant Aspergillus, A. floriformis, developed from a grey desert soil of the Western Desert, Egypt (Samson and Mouchacca 1975). It was then regarded as matching A. peyronelli Sappa. Recently however the species was renamed Emericella floriformis (Samson \& Mouch.) Pitt \& J.A. Taylor (see Pitt and Taylor 2014). No teleomorph has yet developed in the cultures of this fungus.

Cladorrhinum bulbillosum and C. phialophorioides (Mouchacca and Gams 1993) were based on holotypes from desert soils in Egypt. The former develops microsclerotia showing no sign of differentiation; the second produced fertile hyphae often ending in straight, discrete phialides subtending elongate, clavate to ellipsoid conidia. These two Cladorrhinum could not be connected with a teleomorph although some Cladorrhinum-like taxa proved to be anamorphs of Apiosordaria von Arx \& Gams. Recent information stress the former taxon is occasionally involved in opportunistic infections of mammals (Zapater and Scattini 1979). Two others new members were recently added to the genus expanding to nine the list of its included species (Madrid et al. 2011).

The genus Desertella Mouch., has remained monospecific for many years. D. globulifera was defined by its ochre cultures, hyaline, morphologically varied large conidia, 40-60 x 42-64 $\mu \mathrm{m}$, and absence of differentiated conidiophores. The recent $D$. fumimontarum Raja \& Shearer has markedly smaller conidia 32-38 x 16-28 $\mu \mathrm{m}$ (Raja et al. 2007). Gilmaniella macrospora was isolated from salt-marsh soil in Kuwait (Moustafa 1975) and afterwards from Iraqi soils; it was then regarded as a good thermotolerant (Abdullah and Al-Bader 1990). Recent record of this hyphomycete is from the soil of a Spanish date palm plantation (Abdullah et al. 2010).

Finally Eurotium xerophilicum proved to be strongly osmophilic (Samson and Mouchacca 1975). It is able to develop on MEA agar with additional sucrose or glycerine concentrations attaining an $\mathrm{a}_{\mathrm{w}}$ from $0.75-0.79$. The species is however slightly thermotolerant having an optimum growth at $24^{\circ} \mathrm{C}$ with a temperature range of $10-36^{\circ} \mathrm{C}$. 


\section{Conclusions}

Despite the fragmented nature of the present information relating to the Middle East fungal novelties introduced all along the investigated period, some major guidelines could however be extracted. Interest in the mycology of this arid land proved to be continuous after the Second World War. This activity resulted in an increase of our knowledge of the fungi of this region and the concomitant discovery of yet unknown members of the local mycobiota. A fair number of fungal taxa were thus characterised in the sixty post-war years of the last century.

The frequency of the relevant new taxa then proposed appears, however, relatively low when compared to similar reports focusing on other regions of the world in the same period. It follows that for the Middle East large tracts of land still remain unexplored for the diversity of their microscopic organisms. In this eastern part of the Mediterranean Sea, mycology is apparently not yet perceived as an important major scientific discipline, probably in relation to the characteristic prevailing aridity.

More expertise in mycology should thus develop in the Middle East to enhance our knowledge of the biodiversity of its fungal communities. In this connection the establishment of the new 'Assiut University Mycological Centre in October 1999' and the 'Regional Centre for Mycology and Biotechnology in Cairo', are two positive measures in line with the former statement. The development of similar centres in the other states of the region is also awaited.

These specific institutions are basic units for the diffusion of information and expertise on the taxonomy of fungi, first step for the classification of organisms active in the particular mycocoenoses of the arid Middle East. Fungi are presently regarded as interesting bio-tools for the production of valuable molecules. Their local characterisation is the only way for the evaluation of their beneficial and detrimental activities. In the meantime some conservation measures should be adopted to preserve the characteristic natural habitats of the region.

\section{Acknowledgments}

The present document is the outcome of a lecture held at the ' $1^{\text {st }}$ International Conference on Fungal Conservation in the Middle East and North of Africa, Ismailia, Egypt, 18-20 October 2016'. Dr Ahmed Abdel-Azeem, Suez Canal University, patiently encouraged our participation in this scientific event organised in the fertile Nile Valley, full of mycological promises. Dr Paul Kirk is warmly acknowledged for his endeavour to upgrade the present 'arid' repetitive text, particularly rich in cited binomials. My colleague Dr Bruno Dennetière kindly shared his notable experience in the preparation of the Power Point tables, a tedious operation.

\section{References}

Abdullah S. K. and Al-Bader S. M. 1990. On the thermophilic and thermotolerant mycoflora of Iraq. Sydowia 42: 1-7.

Abdullah S. K. and Abbas B. A. 2008. Fungi inhabiting surface sediments of Shatt Al-Arab River and its creeks at Basrah, Iraq. Basrah Journal of Science B26 (1): 68-81.

Abdullah S. K., Monfort E., Asensio L., Salinas J., Lopez L. L. V. and Jansson H. B. 2010. Soil mycobiota of date palm plantations in Elche, SE Spain. Czech Mycology 61(2): 149-162.

Adskavege J. E. and Gilberston R. L. 1989. Cultural studies of four North American species in the Ganoderma lucidum complex with comparison to G. lucidum and G. tsugae. Mycological Research 92: 182-191 (now Fungal Biology).

Badali H., Chander J., Gupta A., Rani H., Punia R.S., Hoog de G. S. and Meis J. F. 2011. Fatal Cerebral phaeohyphomycosis in an immunocompetent individual due to Thielavia subthermophila. Journal of Clinical Microbiology 49: 2336-2341.

Beyma F. H., Thoe Kingma van 1933 a. Beschreibung einiger neuer Pilzarten des Centraalbureau voor Schimmelcultures. Zentralblatt für Bakteriologie, Parasitikunde Infections-krankheiten II Bbt. 88: 132-141. 
Beyma F. H., Thoe Kingma van, 1933 b. Beschreibung einiger neuer Pilzarten aus dem Centraalbureau voor Schimmelcultures. II. Zentralblatt für Bakteriologie, Parasitikunde Infections-krankheiten II Bbt. 89: 236-243.

Bokhary F. E. M. M. 1986. Studies on thermophilic and thermotolerant fungi in the soil of Kingdom of Saudi Arabia. M.Sc. Thesis, Girls College of Education, Jeddah, Kingdom of Saudi Arabia.

Cooney D. G. and Emerson R. 1964. Thermophilic Fungi. An Account of Their Biology, Activities and Classification. W.H. Freeman \& Co., San Francisco and London, 188 pp.

Delile A.-R. 1813. Flora Egyptiacae Illustratio. Paris.

Guarro J., Abdullah S. K., Al-Bader S. M., Figueras M. J. and Gené J. 1996. The Genus Melanocarpus. Mycological Research 100(1): 75-78 (now Fungal Biology).

Ito T. and Nakagiri A. 1979. A mycofloral study on mangrove mud in Okinawa, Japan. IFO Research Communication 18: 32-39.

Kirk P. and Ansell M. E. 2003. Authors of Fungal Names. Index of Fungi Supplement. CAB International, Oxon, UK (electronic version).

Kirk P. M., Cannon P. F., Minter D.W. and Stalpers J. A. 2008. Ainsworth and Bisby's Dictionary of the Fungi, 10th. Ed., CABI Europe-UK.

Madrid H., Cano J., Gené J. and Guarro J. 2011. Two new species of Cladorrhinum. Mycologia 103(4): 795-805.

Melchers L. E. 1931. A check list of plant diseases and fungi occurring in Egypt. Transactions of the Kansas Academy of Sciences 34: 41-106.

Moubasher A. H. 1993. Soil Fungi in Qatar and other Arab Countries. The Scientific and Applied Research Centre, University of Qatar, $566 \mathrm{pp}$.

Moubasher A. H. and Mustafa A. F. 1972. Aspergillus egyptiacus sp. nov. Journal of Botany, United Arab Republic 15: 153-154.

Mouchacca J. 1995. Check-list of novel fungi from the Middle East described mainly from soil since 1930. Sydowia 47: 240-257.

Mouchacca J. 1997. Thermophilic Fungi: Biodiversity and Taxonomic Status. Cryptogamie, Mycologie 18(1): 19-69.

Mouchacca J. 1999. A list of novel fungi described from the Middle East, mostly from non-soil substrata. Nova Hedwigia 68(1-2): 149-174.

Mouchacca J. 2001. Thermophilic fungi and applied research work: a synopsis of name changes and synonymies. World Journal of Microbiology and Biotechnology 16: 881-888.

Mouchacca J. 2004. Novel fungal taxa from the arid Middle East (1940-2000): Omissions from previous notes. Cryptogamie, Mycologie 25(1): 149-171.

Mouchacca J. 2007. Heat-tolerant fungi and applied research: On the taxonomic position of some overlooked thermophilic fungi. Cryptogamie, Mycologie 28: 215-223.

Mouchacca J. and Gams W. 1993. The Hyphomycete Genus Cladorrhinum and its Teleomorph Connections. Mycotaxon 68: 415-440.

Moustafa A. J. 1975. A new species of Gilmaniella from the soil of Kuwait. Persoonia 8: 332333.

Nozawa K., Sevea H., Nakajima S., Udagawa S.-I. and Kawai K.-I. 1987. Studies on fungal products. Part 10. Isolation and structure of novel bicoumarins, desertorins A, B, and C, from Emericella desertorum. Journal of Chemical Society, Perkin Transactions 1: 1735-1738.

Pitt J. I. and Taylor J. W. 2014. List of names in Aspergillus and teleomorphs as proposed by Pitt and Taylor. Mycologia 106: 1051-1062.

Raja H. A., Stchigel A. M., Miller A. N., Crane J. L. and Shearer, C. A. 2007. Hyphomycetes from the Great Smoky Mountains National Park, including three new species. Fungal Diversity 26: 271-286.

Reichert I. 1921. Die Pilzflora Ägyptens. Engler's botanischen Jahrbüchen 56: 595-727. 
Sabet Y. 1935. A preliminary study of Egyptian soil fungi. Bulletin of the Faculty of Science, The Egyptian University, Cairo (Imprimerie MISR S.A.E.), No. 3, 29 pp.

Sabet Y. 1939. On some fungi isolated from soil in Egypt. Bulletin of the Faculty of Science, No. 19, The Fouad I University, Cairo, 112 pp.

Samson R. A. and Mouchacca J. 1974. Some interesting species of Emericella and Aspergillus from Egyptian desert soil. Antonie van Leeuwenhoek 40(1): 121-131.

Samson R. A. and Mouchacca J. 1975. Additional Notes on species of Aspergillus, Eurotium and Emericella from Egyptian desert soil. Antonie van Leeuwenhoek 41(3): 343-351.

Seaward M. R. D. and Sipman H. J. M. 2006. An updated checklist of lichenized and lichenicolous fungi for Egypt. Willdenowia 36 (Special Issue): 537-555.

Sriakshmi J., Madhavi J., Lavanya S. and Ammani K. 2015. Commercial Potential of Fungal Protease: Past, Present and Future Prospects. Journal of Pharmaceutical, Chemical and Biological Sciences 2(4): 218-234.

Subramanian C. V. and Wasser S. P. 2001 (Eds.). Soil Microfungi of Israel (Biodiversity of Cyanoprocaryotes, Algae and Fungi in Israel). Ruggell, A.R.A. Gantner Verlag K.-G., 545 pp.

Theoulakis P., Goldblum D., Zimmerli S., Muehlethaler K. and Fruef B. E. 2009. Keratitis resulting from Thielavia subthermophila Mouchacca. Cornea 28: 1067-1069.

Waller J. M., Lenne J. M. and Waller S. J. 2001. Plant pathologists Pocketbook. 3rd ed. CABI Publishing, Wallingford, Oxon, UK, 516 pp.

Zapater R. C. and Scattini F. 1979. Mycotic keratitits by Cladorrhinum. Sabouraudia 17: 56-69.

\section{Global List of Novelties Reterived}

The political states of the region were first listed in an alphabetical order of their current names. The novel fungi recorded were then segregated following the state of collection of their holotypes. For each providing state, the associated binomials were then grouped on the basis of their taxonomic features at the Class level following the latest system of Classification of the Fungi (Kirk et al. 2008).

The elements of each Taxonomic Class, present in anyone state, were then listed in an alpha-betical order of the original generic names reported in the Index of Fungi. Binomials introduced for the Middle East, and which proved to represent valid taxa, are printed in bold characters, while those of invalidly published or synonymized taxa are reported in simple italics.

For each cited novelty, the basic reference is indicated and this is followed by the present taxonomic state of the fungus. Names introduced for the Middle East and which presently proved to represent valid taxa are then printed in bold characters, while those of invalidly published or synonymized taxa are in simple italics. For the latter, all the available data on the taxonomic and nomenclatural history of the related novelty are then provided.

For each record, the nature of the substrate sustaining the growth of the developing fungi is also precised. Follows the name of the providing state and the abbreviation of the relevant Taxonomic Class; these information were repeated in order to alleviate the negative impact generated by the lenghty lists of names featuring some providing states.

The following abbreviations were used for the Taxonomic Groups: Oomycetes: Oo; Chytri-diales: $\mathrm{Ch}$; Zygomycetes: Zy; Ascomycota: As; Basidiomycota: $\mathrm{Ba}$; and finally Mitosporic Fungi: Mi. Finally a number of recent titles on the Biodiversity of the Middle East fungi are reported after the present Global List.

\section{EGYPT}

Chytridiomycetes: Rhizophydium racemosum A. Gaertn. (as 'Rhizophidium' ) - Arch. Mikrobiol. 21: 125. 1954, nom. invalid. , Art. 39.1 (Melbourne); now R. racemosum A. Gaertn., ex Letcher, 
in Letcher \& Powell - Publication of the Zoosporic Research Institute 1: 93. 2012. Isolated from a damp soil. Egypt. (Ch)

Ascomycetes: Achaetomium cristalliferum Faurel \& Locq.-Lin., in Locquin-Linard - Cryptog. Mycol. 1: 235. 1980; a present synonym of Chaetomium strumarium (J.N. Rai, J.P. Tewari \& K.G. Mukerji) P.F. Cannon - Trans. Br. Mycol. Soc. 87: 64. 1986 (三 Achaetomium strumarium J.N. Rai, J.P. Tewari \& K.G. Mukerji - Can. J. Bot. 42: 694. 1964). Isolated from a grey desert soil. Egypt. (As)

Arnium bellum N. Lundq. - Svensk Bot. Tidskr. 68: 290. 1974. Developed on rodent dung incubated in a damp chamber. Egypt. (As)

Ascobolus egyptiacus Mouch. - In 'Travaux dédiés à G. Viennot-Bourgin', Société Française de Phytopathologie, Paris: 266. 1977. Isolated from a grey desert soil. Egypt. (As)

Chaetomiopsis dinae Mustafa \& Abdel-Wahid - Mycologia 82: 129-131. 1990; type species of the genus Chaetomiopsis Mustafa \& Abdel-Wahid. The species was dedicated by Prof. Mustafa to his daughter Dina. Isolated from an agricultural soil. Egypt. (As)

Chaetomium gelasinosporum Aue \& E. Müll. - Ber. Schweiz. Bot. Ges. 77: 193. 1967. Isolated from soil of a lupin field. Egypt. (As)

Chaetomium mareoticum Besada \& Yusef - Proceedings of the Egyptian Academy of Sciences 21: 107. 1968 [? 1970], nom. invalid., Art. 36.1 ICBN. Chaetomium mareoticum Besada \& Yusef - Trans. Br. mycol. Soc. 52(3): 502. 1969: Latin diagnosis provided. Isolated from a desert soil on the Mediterranean Sea coast close to Alexandria city. Egypt. (As)

Chaetomium sinaiense Mustafa \& Ezz-ElDin (as `Ess El-Din') - Can. J. Bot. 67: 3417. 1989. Isolated from a coastal salt-marsh soil. Egypt. (As)

Chaetomium uniporum Aue \& E. Müll. - Ber. Schweiz. Bot. Ges. 77: 189. 1967. Isolated from soil of a lupin field. Egypt. (As)

Emericella desertorum Samson \& Mouch. - Antonie van Leeuwenhoek 40: 121. 1975; present name Aspergillus desertorum (Samson \& Mouch.) Samson, Visagie \& Houbraken, in Samson et al. - Stud. Mycol., Utrecht 78: 155. 2014, although no anamorphic state develops in cultures of the type strain. Isolated from a grey desert soil. Egypt. (As)

Emericella purpurea Samson \& Mouch. - Antonie van Leeuwenhoek 41: 350. 1975; anamorph: Aspergillus purpureus Samson \& Mouch. - Ibidem 41: 350. 1975. Isolated from a grey desert soil. Egypt. (As)

Eupenicillium sinaicum Udagawa \& S. Ueda - Mycotaxon 14(1): 266. 1982; anamorph: Penicillium sinaicum Udagawa \& S. Ueda - Ibidem 14(1): 266. 1982. Isolated from a sample of marine sludge. Egypt. (As)

Eurotium xerophilum Samson \& Mouch. (as 'xerophilus') - Antonie van Leeuwenhoek 41(3): 348. 1975; anamorph: Aspergillus xerophilus Samson \& Mouch. - Ibidem 41(3): 348. 1975. Isolated from a grey desert soil. Egypt. (As)

Gelasinospora hippopotama J.C. Krug, R.S. Khan \& Jeng - Mycologia 86: 250. 1994; renamed Neurospora hippopotama (J.C. Krug, R.S. Khan \& Jeng) Dania Garcia, Stchigel \& Guarro - Mycol. Res. 108(10): 1129. 2004. Isolated from soil maintained in a humid chamber. Egypt. (As)

Lasiobolidium aegyptiacum Mustafa \& Ezz-el-Din - Mycol. Res. 92(3): 377. 1989. Developed from a coastal salt-marsh soil. Egypt. (As)

Octospora tetraspora var. egyptiaca J. Moravec (as 'aegyptiaca') - Ceska Mykol. 26(3): 138. 1972; now Byssonectria tetraspora (Fuckel) Korf - Phytologia 21(4): 202. 1971 [三 Ascobolus tetraspora Fuckel - Hedwigia 5(1): 4. 1866]. Developed on the thallus of the moss Bryum argentum growing in a flowerpot with the plant Draceana sp., The Anderson Museum, Cairo, 28 Apr. 1970, leg. J. Moravec. Egypt. (As) 
Podospora egyptiaca N. Lundq. (as 'aegyptiaca') - Svensk Bot. Tidskr. 64(4): 409. 1970. Developed on sheep dung incubated in a damp chamber. Egypt. (As)

Podospora faurelii Mouch. - Revue Mycol., Paris 38(3-4): 109. 1973; a present synonym of Zopfiella karachiensis (S.I. Ahmed \& Asad) Guarro, in Guarro \& Cano - Trans. Br. Mycol. Soc. 91(4): 589. 1988. Isolated from a grey desert soil. Egypt. (As)

Pseudeurotium desertorum Mouch. (as 'Pseudoeurotium') - Ibidem 36: 125. 1971. Isolated from a reclaimed desert soil cultivated with wheat. Egypt. (As)

Rhexothecium globosum Samson \& Mouch. - Can. J. Bot. 53: 1637. 1975; type species of the genus Rhexothecium Samson \& Mouch. From a grey desert soil. Egypt. (As)

Talaromyces assiutensis Samson \& Abdel-Fattah - Persoonia 9: 501. 1978; anamorph: Penicillium assiutense Samson \& Abdel-Fattah - Ibidem 9: 501. 1978. The proposal of the variety T. trachyspermus var. assiutensis (Samson \& Abdel-Fattah) Yagichi \& Udagawa Mycoscience 35(1): 64. 1994, has apparently not gained wide acceptance. Isolated from a cultivated soil amended with crushed buffalo hooves. Egypt. (As)

Thermoascus egyptiacus S. Ueda \& Udagawa (as 'aegyptiaca') - Trans. Mycol. Soc. Japan 24(2): 135. 1983; anamorph: Paecilomyces egyptiacus S. Ueda \& Udagawa (as 'aegyptiaca') - Ibidem 24(2): 135. 1983; present name Coonemeria aegyptiaca (S. Ueda \& Udagawa) Mouch. - Cryptog. Mycol. 18(1): 31. 1997. Isolated from a sample of marine sludge. Egypt. (As)

Thielavia egyptiaca Mustafa \& Abdel-Wahid (as 'aegyptiaca') - Persoonia 14(2): 173. 1990. Isolated from a cultivated soil. Egypt. (As)

Thielavia arenaria Mouch. - Bull. Trimest. Soc. Mycol. Fr. 89(3-4): 308. 1973. Isolated from a sand dune. Egypt. (As)

Thielavia microspora Mouch. - Ibidem 89(3-4): 308. 1973. Isolated from a sand dune. Egypt. (As)

Thielavia subthermophila Mouch. - Ibidem 89(3-4): 310. 1973. Isolated from a grey desert soil. Egypt. (As)

Zygopleurage faiyumensis N. Lundq. - Bot. Notiser 122: 354. 1969. Developed on cow dung incubated in a damp chamber. Egypt. (As)

Mitosporic Fungi: Alternaria chlamydospora Mouch. (as 'chlamydosporum') - Mycopath. Mycol. Appl. 50(3): 217. 1973. Isolated from a grey desert soil. Egypt. (Mi)

Aspergillus egyptiacus Moub. \& Mustafa (as 'egyptianus' and 'aegyptiacus') - J. Bot., Un. Arab Repub. 15(1): 153. 1972. Isolated from soil of an olive tree plantation. Egypt. (Mi)

Aspergillus flaschentraegeri Stolk - Trans. Br. Mycol. Soc. 47(1): 123. 1964. Isolated from the intestine of a Prodenia litura larva. The species was dedicated to the late Dr. B. Flaschenträeger, a visiting Professor of Biochemistry at Alexandria University where he isolated the relevant type strain [Flaschenträeger B. and Soliman H.T., 1959 - Diseases of the larvae of Prodenia litura. Antonie van Leeuwenhoek, J. Microbiol. Serol. 25: 67-72]. Egypt. (Mi)

Aspergillus floriformis Samson \& Mouch. - Antonie van Leeuwenhoek 41: 343. 1975. Isolated from a grey desert soil. Egypt. (Mi)

Aspergillus pseudodeflectus Samson \& Mouch. - Ibidem 41: 345. 1975 [= A. ustus var. pseudodeflectus (Samson \& Mouch.) Kozak. - Mycol. Pap. 161: 131. 1989]. Isolated from a grey desert soil. Egypt. (Mi)

Botrytis septospora El-Helaly, Elarosi, Assawah \& Kilani - Phytopath. Mediterr. 1: 39. 1962; nom. invalid. , Art. 39.1 (Melbourne). Isolated from decayed stored bulbs of Allium cepa. Egypt. (Mi)

Cephalosporium maydis Samra, Sabet \& Hing. - Phytopathology 53: 404. 1963; renamed Magnaporthiopsis maydis (Samra, Sabet \& Hing.) Klaubauf, Lebrun \& Crous, in Kau- 
bauf, Tharreau, Fournier, Groenewald, Crous, de Vries \& Lebrun - Stud. Mycol., Utrecht 79: 101. 2014. Isolated from infected roots and stems of Zea mays. Egypt. (Mi)

Cladorrhinum bulbillosum W. Gams \& Mouch., in Mouchacca \& Gams - Mycotaxon 68: 425. 1993. Isolated from an abandoned field in the Dakhlah oasis, Western Desert of the country. Egypt. (Mi)

Cladorrhinum phialophoroides Mouch. \& W. Gams - Ibidem 68: 428. 1993. Original strain isolated from a reclamed desert soil cultivated with wheat. Egypt. (Mi)

Desertella globulifera Mouch. - Revue Mycol., Paris 43(1): 73. 1979; type species of the genus Desertella Mouch. Isolated from a ferruginous desert soil. Egypt. (Mi)

Drechslera subpapendorfii Mouch. - Ibidem 38: 102. 1973; now redisposed as Curvularia subpapendorfii (Mouch.) Manamgoda, Rossman \& H.K. Hyde - A taxonomic and phylogenetic reappraisal of the genus Curvularia 79: 282. 2014 [= Bipolaris subpapendorfii (Mouch.) Alcorn - Mycotaxon 17: 69. 1983]. Isolated from a grey desert soil. Egypt. (Mi)

Exserohilum oryzinum Sivan. - Trans. Br. Mycol. Soc. 83(2): 325. 1984. Original strain developed on living leaves of Oryza sp. Egypt. (Mi)

Fusariella aegyptiaca Mouch. (as 'aegyptiacum'), in Mouchacca \& Nicot - Revue Mycol., Paris 37(3): 181. 1972 [1973]. Isolated from a grey desert soil. Egypt. (Mi)

Geotrichum novakii El-Masry \& Zsolt - Acta Biol., Szeged, N.S., 12(3-4): 69. 1966 [1967]; a present synonym of Dipodascus geotrichum (E.E. Butler \& L.J. Petersen) Arx Antonie van Leeuwenhoek 43: 336. 1977. Isolated from decaying fruits of Prunus persica. Egypt. (Mi)

Gilmaniella multiporosa Mustafa \& Ezz ElDin - Mycol. Res. 92(4): 502-505. 1989. Original strain obtained from a salt-marsh soil. Egypt. (Mi)

Idriella desertorum Mouch, in Nicot \& Mouchacca - Revue Mycol., Paris 36(3-4): 192. 1971 (1972)]; present name Neoidriella desertorum (Mouch.) M. Hern.-Restr. \& Crous, in Hernandez-Restrepo, Groenewald \& Crous - Persoonia, Molecular Phylogeny and Evolution of Fungi 37: 78. 2015 [2016]. Isolated from a grey desert soil. Egypt. (Mi)

Macrosporium macrosporum (A. Zimm.) Morsy (as 'macrospora') - Agric. Res. Rev., Cairo 47: 163. 1969; nom. invalid. , Art. 32.5 ICBN, and a duplicate of the former published combination M. macrosporum (A. Zimm.) Nishikado \& Oshima - Nögaku-Kenkyü [Agric. Res. (Kurashiki)] 36: 391. 1944. Macrosporium Fr. was subsequently rejected against Alternaria Nees by Hughes [Hughes S.J. 1958 - Revisiones Hyphomycetum aliquot. Can. J. Bot. 36: 727836].

The present legal name of this fungus is Alternaria macrospora A. Zimmermann - Ber. Land. - Forstw. Deutsch-Ostafrika 2: 24. 1904 [= Sporidesmium longipedicillatum Reichert Bot. Jahrb. Syst. (Engler) 56: 723. 1921, also observed on leaves of Gossypium sp. in Egypt; see Mouchacca J. 2006 - Novel fungal taxa from the arid Middle East introduced prior to the year 1940. II - Anamorphic Fungi: Hyphomycetes. Cryptog. Mycol. 30(2): 199-222; = Alternaria longipedicellata (Reichert) Snowden - Uganda Protectorate, Ann. Rept. Dept. Agric.: 31.1926 (1927)]. Developed on living leaves of Cotton plants. Egypt. (Mi)

Mucobasispora tarikii Mustafa \& Abdul-Wahid - Mycol. Res. 94: 131. 1990; type species of the genus Mucobasispora Mustafa \& Abdul-Wahid. The species was dedicated by A.F. Mustafa to his son Tarik. Isolated from the soil of a Tomato field. Egypt. (Mi)

Penicillium allii Vincent \& Pitt - Mycologia 81(2): 300. 1989; a synonym of P. hirsutum Dierckx - Ann. Soc. Sci. Bruxelles. Developed in the United States on gloves of garlic (Allium sativum) imported from the Nile Valley. Egypt. (Mi)

Scopulariopsis hanii Mustafa \& Abdel-Wahid - Nova Hedwigia 51: 476. 1990. The species dedicated to the first author's son Hani. Isolated from a cultivated soil. Egypt. (Mi) 
Setosporella mahmoudii Mustafa \& Abdel-Wahid - Mycol. Res. 93: 228. 1989; type species of the genus Setosporella Mustafa \& Abdul-Wahid. Isolated from a cultivated soil. Egypt. (Mi)

Trichocladium ismailiense Mustafa \& Ezz-ElDin - Nova Hedwigia 50: 255. 1990. Isolated from a salt-marsh soil. Egypt. (Mi)

Trichosporon pharaonis Maged, Ghanem \& Reffaat [as 'pharoni'] - In Razak A.A. (ed.), Second Regional Mycological Conference, Abstracts, University of Al-Azhar, Cairo, Egypt, 710 Ocotober 1992 (Cairo, Egypt, University of Al-Azhar): 14. 1992; nom. invalid. , Arts. 39.1, 40.1, 40.4, 40.5 (Melbourne). Isolated as an air-borne fungus from an old Pharaonic tomb. Egypt. (Mi)

Ulocladium chlamydosporum Mouch. - Rev. Mycol., Paris 36: 120. 1971; now Alternaria mouchaccae E.G. Simmons - Mycotaxon 13: 18. 1981, a new name. Isolated from an abandoned field in the Dakhlah oasis. Egypt. (Mi)

Ulocladium microsporum Moub. \& Abdel-Hafez - Trans. Br. mycol. Soc. 69(1): 164. 1977; now a synonym of Alternaria didymospora (Munt.-Cvetk.) Woudenb. \& Crous - Stud. Mycol., Utrecht 75(1): 199. 2013 (三Embellisia didymospora Munt.-Cvetk. - Mycologia 68: 49. 1976). Isolated from a cultivated soil. Egypt. (Mi)

Veronaea constricta Mustafa \& Abdel-Wahid - Mycotaxon 38: 167. 1990. Isolated from a cultivated sandy loam soil. Egypt. (Mi)

\section{IRAQ}

Oomycetes: Calyptralegnia basraensis Muhsin - Polskie Archivum Hydrobiologii 41(4): 415. 1994. Isolated from a water sample of the Shatt Al-Arab River. Iraq. (Oo)

Ascomycetes: Arxiomyces zuberiensis N. Abdullah \& Al-Saadoon (as 'zubairiensis') - Marina Mesopotamica 9: 246. 1994. Developed on dead stems of Phragmites australis. Iraq. (As)

Chaetomium mesopotamicum Abdullah \& Zora - Cryptog. Bot. 3: 387. 1993; a thermophilic fungus. Isolated from soil of a date palm plantation. Iraq. (As)

Chaetomium subcurvisporum Abdullah \& Al-Bader - Int. J. Mycol. Lichenol. 4: 84. 1989; a thermotolerant fungus. Isolated from forest soil. Iraq. (As)

Coniochaetidium nuciforme Guarro, Gené, Al-Bader \& Abdullah - Mycoscience 38(2): 123. 1997; renamed Coniochaeta nuciformis (Guarro, Gené, Al-Bader \& Abdullah) Dania García, Stchigel \& Guarro (as 'nuciforme'), in García, Stchigel, Cano, Calduch, Hawksworth \& Guarro - Mycol. Res. 110(11): 1284. 2006. Isolated from forest soil. Iraq. (As)

Corynascella arabica Guarro, Al-Saadoon, Gené \& Abdullah - Mycologia 89: 955. 1997. Developed on donkey dung incubated in a damp chamber. Iraq. (As)

Emericella similis Y. Horie, Udagawa, Abdullah \& Al-Bader - Trans. Mycol. Soc. Japan 31(4): 425. 1990; anamorph: Aspergillus similis (Y. Horie, Udagawa, Abdullah \& Al-Bader) Samson, Visagie \& Houbraken - Stud. Mycol., Utrecht 78: 157. 2014. Isolated from soil of a date palm plantation. Iraq. (As)

Iodophanus basraneous Abdullah, Ismail \& S.S. Rattan - Nova Hedwigia 28(2-3): 243. 1977. Developed on sheep dung incubated in a damp chamber. Iraq. (As)

Monascus pallens P.F. Cannon, Abdullah \& Abbas - Mycol. Res. 99: 661. 1995; a thermotolerant fungus. Isolated from decaying plant material as sediments on the banks of the Shatt Al-Arab River. Iraq. (As)

Monascus sanguineus P.F. Cannon, Abdullah \& Abbas - Ibidem 99: 661. 1995. Isolated from decaying plant material as sediments on the banks of the Shatt Al-Arab River. Iraq. (As)

Podospora euphratica Abdullah - Nova Hedwigia 44: 345. 1987. Developed on sheep dung incubated in a damp chamber. Iraq. (As) 
Preussia aquilirostrata Guarro, Abdullah, Gené \& Al-Saadoon - Mycol. Res. 101(3): 305. 1997. Isolated from dead leaf bases of Phoenix dactylifera. Iraq. (As)

Preussia constricta Guarro, Al-Saadoon \& Abdullah - Nova Hedwigia 64: 177. 1997. Developed on sheep dung incubated in a damp chamber. Iraq. (As)

Preussia hexaphragmia Guarro, Al-Saadoon \& Abdullah - Ibidem 64: 178. 1997. Developed on sheep dung incubated in a damp chamber. Iraq. (As)

Preussia variispora Abdullah, Al-Saadoon \& Guarro - Ibidem 69(1-2): 211. 1999. On sheep dung incubated in a damp chamber. Iraq. (As)

Sphaerodes irakuiensis Abdullah \& Abbas - Marina Mesopotamica 9: 206. 1994. Developed on decaying plant material as surface sediments of the Shatt Al-Arab River. Iraq. (As)

Strattonia mesopotamica Abdullah - Trans. Br. mycol. Soc. 81: 393. 1983; present name Podospora mesopotamica (Abdullah) Guarro, P.F. Cannon \& Aa - Syst. Ascomycetum 10: ? 1991. Developed on donkey dung incubated in a damp chamber. Iraq. (As)

Syspastospora tetraspora Abdullah \& Al-Saadoon - Marina Mesopotamica 9: 85. 1994; the species was not re-evaluated since its description although new taxa were subsequently reported to Syspastospora Cannon \& Hawksworth [Garcia D., Stchigel A.M. \& Guarro J. 2002 A new species of Syspastospora from tropical soils. Mycologia 94(5): 862-869]. Developed on dead stem parts of Arundo donax. Iraq. (As)

Thielavia minuta var. thermophila Abdullah \& Al-Bader - Basrah J. Agric. Res. 5: 115120. 1992; present name Melanocarpus thermophilus (Abdullah \& Al-Bader) Guarro, Abdullah \& Al-Bader, in Guarro et al. - Mycol. Res. 100: 75. 1996; a thermophilic ascomycete. Isolated from a forest soil. Iraq. (As)

Zopfiella cephalothecoidea Guarro, Abdullah, Al-Saadoon \& Gené - Mycotaxon 59: 198. 1996. Developed on dead twigs of an unknown plant. Iraq. (As)

Zopfiella submersa Guarro, Al-Saadoon, Gené \& Abdullah - Mycologia 89: 958. 1997. Developed on submerged culms of Phragmites sp. in the Euphrates River. Iraq. (As)

Basidiomycetes: Aecidium tami Z. Urb. , in Guyot - Uredineana 6: 11. 1966. Developed on living leaves of Tamus communis. Iraq. (Ba)

Galzinia cystidiata S.S. Rattan \& Abdullah - Indian Phytopath. 29: 296. 1976 (1977). Growing on wood of Pinus halepensis var. brutiae. Iraq. (Ba)

Hyphoderma puberum var. dactyliferum S.S. Rattan \& Al-Dboon (as 'pubera var. dactylifera') - Sydowia 33: 254. 1980; a present synonym of Peniophorella pubera (Fr.) P. Karst. Bidr. Känn. Finl. Nat. Folk 48: 427. 1889 (三 Hyphoderma puberum (Fr.) Wallr. - Fl. Crypt. Germ. (Norimbergae) 2: 576. 1833). A common white rot fungus of local date-palms. Iraq. (Ba)

Puccinia hadacii Z. Urb., in Guyot - Uredineana 6: 25. 1966. Observed on living leaves of Carduus pycnocephalus. Iraq. (Ba)

Uredo fragrantissima Z. Urb., in Guyot - Ibidem 6: 44. 1966. Developed on living leaves of Achillea fragrantissima. Iraq. (Ba)

Uromyces acantholimonis var. zagrosica Z. Urb., in Guyot - Ibidem 6: 46. 1966. On living leaves of Acantholimon sp. Iraq. (Ba)

Mitosporic Fungi: Ascochytella thymi Petr. - Annln K.K. naturh. Hogmus. Wien 52: 367. 1941 [1942]; now renamed Pseudodiplodia thymi (Petr.) Petr. - Sydowia 7(5-6): 305. 1953. Developed on dead twigs of Thymus syriacus. Iraq. (Mi)

Exserohilum curvisporum Sivan., Abdullah \& B.A. Abbas - Mycol. Res. 97: 1486. 1993. Isolated from decomposing plant material on the Shatt Al-Arab River banks. Iraq. (Mi)

Stachybotrys guttulispora Muhsin \& El-Helfi - Sydowia 34: 133. 1981. Isolated from a sample of stagnant water of the Shatt Al-Arab River. Iraq. (Mi) 
Stanjemonium fuscescens W. Gams, Schroers \& Abdullah, in Gams, O'Donnell, Schroers \& Christensen - Can. J. Bot. 76(9): 1580. 1998 [1999]. From desert soil. Iraq. (Mi)

Thermophymatospora fibuligera Udagawa, Awao \& Abdullah - Mycotaxon 37: 100. 1986; type species of the genus Thermophymatospora Udagawa, Awao \& Abdullah; a thermotolerant fungus provided with clamp connections at the transverse septa. Later on reported as the anamorph of Tomophagus colossus (Fr.) Murrill [= Ganoderma colossus (Fr.) C.F. Baker]. Isolated from soil of a date palm plantation. Iraq. (Mi)

Trichurus dendrocephalus Udagawa, Y. Horie \& Abdullah - Ibidem 23: 253. 1985. Isolated from soil of a date palm plantation. Iraq. (Mi)

\section{JORDAN}

Ascomycetes: Coniochaeta nodulosporioides D. Hawksw. - Norw. J. Bot. 25: 15. 1978; renamed Coniocessia nodulisporioides (D. Hawksw.) Dania Garcia, Stchigel, D. Hawksw. \& Guarro - Mycol. Res. 110(11): 1284. 2006. Isolated from a cultivated soil. Jordan. (As)

Mitosporic Fungi: Cylindrotrichum gorii Lunghini - Micol. Ital.: 25. 1979. Isolated from leaf litter. Jordan. (Mi)

Humicola hyalothermophila Moub., Mazen \& Abdel-Hafez - Trans. Br. Mycol. Soc. 72(3): 509. 1979; a thermophilic fungus. Isolated from a cultivated soil. Jordan. (Mi)

\section{KUWAIT}

Ascomycetes: Arachniotus desertorum Mustafa (as 'Moustafa') - Trans. Br. Mycol. Soc. 61: 392. 1973; a synonym of Gymnascella confluens (Sartory \& Bainier) Currah - Mycotaxon 24: 75. 1985. Isolated from a salt-marsh soil. Kuwait. (As)

Petriellidium desertorum Arx \& Mustafa, in Arx - Persoonia 7: 371. 1973; now Pseudallescheria desertorum (Arx \& Mustafa) Mc Ginnis et al. - Mycotaxon 14: 98. 1982; anamorph Scedosporium desertorum (Arx \& Moustafa) Lackner \& de Hoog, in Lackner et al. Fungal Diversity 67: 9. 2014. Isolated from a salt-marsh soil. Kuwait. (As)

Pleospora eucalypti J.L. Mulder - Mycol. Res. 92: 116. 1989. Developed on bark of Eucalyptus camadulensis. Kuwait. (As)

Thielavia kuwaitensis Mustafa (as 'Moustafa') - Trans. Br. Mycol. Soc. 66: 336. 1976; a synonym of Thielavia coactilis Nicot, in Nicot \& Longis - C. r. hebd. Séances Acad. Sci., Paris 253: 304. 1961 [see Mouchacca J. 1985 - Redécouverte du Thielavia coactilis Nicot, un ascomycète observé sur des feuilles mortes de Carpinus, et ses rapports avec certaines espèces de ce genre. Persoonia 12(4): 441-446]. Isolated from a salt-marsh soil. Kuwait. (As)

Mitosporic Fungi: Chrysosporium zonatum Al-Musallam \& C.S. Tan - Persoonia 14: 69. 1989; teleomorph: Aphanoascus orissi (B. Sur \& G.R. Ghosh) Cano \& Guarro, in Cano et al. - Stud. Mycol., Baarn 47: 158. 2002 [三 Pseudoarachniotus orissi B. Sur \& G.R. Ghosh, in Ghosh \& Sur - Kavaka 12: 67. 1985]. Developed on hair baits immersed in horse dung. Kuwait. (Mi)

Cirrenalia basiminuta Raghuk. \& Zainal, in Raghu-Kumar, Zainal \& Jones - Mycotaxon 31(1): 183. 1988. Observed on wood test blocks of Pinus sylvestris submerged in the sea. Kuwait. (Mi)

Gilmaniella macrospora Mustafa - Persoonia 8(3): 332. 1975. Isolated from a salt-marsh soil. Kuwait. (Mi)

Hyalocladium moubasheri Mustafa (as 'moubasherii') - Trans. Br. Mycol. Soc. 67(3): 537. 1976 [1977]; type species of the genus Hyalocladium Mustafa. Isolated during a survey of air-borne fungi. Kuwait. (Mi)

Sporothrix ranii Mustafa - Persoonia 11: 392. 1981. Isolated from a tidal salt-marsh soil. Kuwait. (Mi) 


\section{LEBANON}

Oomycetes: Pythium orthogonon Ahrens - Z. Pflkrankh. Pflschutz 78(3): 177. 1971; renamed Globisporangium orthogonon (Ahrens) Uzuhashi, Tojo \& Kakish. - Mycoscience 51(5): 362. 2010. Isolated from roots of Zea mays. Lebanon. (Oo)

Ascomycetes: Didymella syriaca Petr. - Sydowia 1(1-3): 41. 1947. Developed on dead stems of Phlomis bervilabris. Lebanon. (As)

Neobroomella ciliata Petr. - Sydowia 1(1-3): 5. 1947; type species of the genus Neobroomella Petr. On dead stems of Phlomis brevilabris. Lebanon. (As)

Thryptospora singularis Petr. (as 'singularia') - Sydowia 1(1-3): 52. 1947; type species of the genus Thryptospora Petr. On dead twigs of Phlomis brevilabris. Lebanon. (As)

Mitosporic Fungi: Pestalotia insueta Petr. (as `Pestalozzia') - Sydowia 1(1-3): 7.1947. Developed on dead stem pieces of Phlomis brevilabris. Lebanon. (Mi)

Plenodomus syriacus Petr. - Sydowia 1: 42. 1947; now Phoma syriaca (Petr.) Boerema, Loer. \& Hamers - Persoonia 16: 180. 1996. Developed on dead stems of Phlomis brevilabris. Lebanon. (Mi)

Stegonsporium centaureae Rayss (as 'Steganosporium') - Bull. Trimest. Soc. mycol. Fr. 62 : 38. 1946. Developed on dry twigs of Centaurea dumulosa. Lebanon. (Mi)

\section{LIBYA}

Ascomycetes: Laboulbenia felicis-caprae W. Rossi (as 'feliciscaprai') - Doriana 5(215): 1. 1974; nom. invalid. , Art. 37.1 ICBN. Developed on the African termite Anacanthotermes ochreceus. Libya. (As)

Saccobolus parvisporus Brumm. - Persoonia 8: 425. 1976. Developed on donkey dung maintained in a damp chamber. Libya. (As)

Saccobolus purpureus Brumm. - Ibidem 8: 423. 1976. Developed on donkey dung maintained in a damp chamber. Libya. (As)

Mitosporic Fungi: Nematoctonus tripolitanius Giuma \& R.C. Cooke - Trans. Br. Mycol. Soc. 59(2): 215. 1972; present name Hohenbuehelia tripolitania (Giuma \& R.C. Cooke) Thorn Index Fungorum 16: 1. 2013. Observed on an unidentified rhabditid nematode of an olive-grove soil. Libya. (Mi)

\section{OMAN}

Myxomycetes: Dictyostelium arabicum H. Hagiw. - Bull. Natn. Sci. Mus., Tokyo, B 17(3): 110. 1991. Developed on the humus layer of grassland, field and orchard. Oman. (My)

Ascomycetes: Chaetomidium khodense Cano, Guarro \& El Shafie - Mycotaxon 49: 399. 1993. Developed on cow dung incubated in a damp chamber. Oman. (As)

Coprotus dhofarensis Gené, El Shafie \& Guarro - Ibidem 46: 276. 1993. Developed on goat dung incubated in a damp chamber. Oman. (As)

Emericella omanensis Y. Horie \& Udagawa - Mycoscience 36: 391. 1996; anamorph: Aspergillus omanensis Y. Horie \& Udagawa - Ibidem 36: 391. 1996. Isolated from forest soil. Oman. (As)

Thecotheus harasisus Gené, E1 Shafie \& Guarro - Mycotaxon 46: 280. 1993. Developed on Oryx dung incubated in a damp chamber. Oman. (As)

\section{PALESTINE-ISRAEL}

Myxomycete: Physarum rayssiae Ramon - Israël J. Bot. 17: 209. 1968 [1969]. Collected on 
dead pine needles lying on the soil. Israel. (My)

Tetramyxa marina Lipkin \& Avidor - Nova Hedwigia 25(3-4): 809. 1974. A plasmodiophoracean marine parasite. Israel. (My)

Oomycetes: Peronospora medicaginis-orbicularis Rayss - Palestine J. Bot., Jerusalem Series 3: 157. 1945. Developed on living leaves of Medicago orbicularis. Palestine. (Oo)

Peronospora rumicis-rosei Rayss - Ibidem 3: 154. 1945. Observed on living leaves of Rumex cyprinus. Palestine. (Oo)

Peronospora trifolii-cherleri Rayss - In Probleme Actuale de Biologie si Stiinte Agricole, Academia Republici populare Romîne: 201. 1961; nom. invalid. , Art. 37.1 ICBN. On living leaves of Trifolium cherleri. West Bank (Palestine). (Oo)

Peronospora trifolii-clypeati Rayss - Ibidem: 198. 1961; nom. invalid. , Art. 37.1 ICBN. On living leaves of Trifolium clypeatum. West Bank (Palestine). (Oo)

Peronospora trifolii-formosi Rayss - Ibidem: 198. 1961. Observed on living leaves of Trifolium dasyurum. West Bank (Palestine). (Oo)

Peronospora trifolii-pilularis Rayss - Ibidem: 200. 1961; nom. invalid., Art. 37.1 ICBN. On living leaves of Trifolium pilularis. West Bank (Palestine). (Oo)

Peronospora trifolii-purpurei Rayss - Ibidem: 197. 1961; nom. invalid. , Art. 37.1 ICBN. On living leaves of Trifolium purpureum. West Bank (Palestine). (Oo)

Peronospora veronicae-cymbalariae Rayss - Palestine J. Bot., Jerusalem Series 3: 160. 1945. On living leaves of Veronica cymbularia. West Bank (Palestine). (Oo)

Sclerophthora Iolii R.G. Kenneth - Israël J. Bot. 12: 139. 1964. Reported on living leaves of Lolium rigidum (wild rye grass). Israel. (Oo)

Sclerophthora rayssiae R.G. Kenneth, Koltin \& I. Wahl - Bull. Torrey bot. Club 91: 189. 1964. Collected on living leaves of Hordeum vulgare. Israel. (Oo)

Chytridiomycetes: Synchytrium aureum Rayss (as 'S. aureum Schröter-Cohn') - Palestine J. Bot., Jerusalem Series 2: 247. 1942: binomial not published by Rayss; now Synchytrium helianthemum Karling (proposed as a new name) - Sydowia Beihefte, Festschrift für Franz Petrak: 247. 1957; nom. invalid. , Art. 36.1 ICBN. On living leaves of Helianthemum salicifolium. Palestine. (Ch)

Urophlyctis astomae Rayss - Palestine J. Bot., Jerusalem Series 2: 248. 1942; now Physoderma astomatis (Rayss) Karling (as 'astomae') - Lloydia 13: 60. 1950. On stems, petioles and living leaves of Astoma sessifolium. Palestine. (Ch)

Urophlyctis eryngii Rayss - Ibidem 2: 248. 1942; now Physoderma rayssii Karling [published as Physoderma Rayssi (Rayss), a new name] - Lloydia 13(1): 60. 1950. Observed on living leaves of Eryngium creticum. Palestine. (Ch)

Zygomycetes: Actinomucor corymbosus f. palaestinus Rayss (as 'palaestina') - Palestine J. Bot., Jerusalem Series 3: 162. 1945 [1946]; nom. invalid., Art. 36.1 ICBN; validated as Actinomucor corymbosus f. palaestinus Rayss - Mycopath. Mycol. Appl. 10(2): 143. 1958. A present synonym of Actinomucor elegans (Eidam) C.R. Benj. \& Hesselt. - Mycologia 49: 241. 1957. Isolated from a garden soil. Palestine. (Zy)

Adlerocystis ornithodori Feldm.-Muhs. \& Havivi - Parasitology 53: 187. 1963; nom. invalid., Arts. $36.1 \& 37.1$ ICBN. Isolated from sperm cells of the tick Ornithodoros tholozani. Israel. (Zy)

Adlerocystis parkeri Feldm.-Muhs. \& Havivi - Ibidem 53: 187. 1963; nom. invalid., Arts. $36.1 \& 37.1$ ICBN. Type species of the genus Adlerocystis Feldm.-Muhs. \& Havivi. From the sperm material present in the uterus of female ticks of Ornithodoros tholozani. Israel. (Zy)

Entomophthora israelensis Ben Ze'ev \& Zelig - Mycotaxon 21: 466. 1984. Developed 
on infected Diptera insects identified as Cecidiomyid midge. Israel. (Zy)

Entomophthora turbinata R.G. Kenneth - Ibidem 6(2): 388. 1977; now Thaxterosporium turbinatum (R.G. Kenneth) R.G. Kenneth \& Ben Ze'ev - Ibidem 28(2): 323. 1987 [= Thaxterosporium turbinatum (R.G. Kenneth) Ben Ze'ev \& R.G. Kenneth - Fundamental and Applied Aspects of Invertebrate Pathology: 218. 1986; = Neozygites turbinata (R.G. Kenneth) Remaud. \& S. Keller - Mycotaxon 11(1): 332. 1980]. Infecting the peach trunk aphid Pterochloroides persicae. Israel. (Zy)

Rhopalomyces elegans f. minor Rayss - Palest. J. Bot., Jerusalem Series 5: 20. 1950; nom. invalid., Art. 36.1 ICBN; now Rhopalomyces elegans var. minor (Rayss) J.J. Ellis - Mycologia 55: 189. 1963. Developed on apothecia of the fungus Sepultaria arenosa (Fück.) Rehm. Israel. (Zy)

Zoophthora erinacea Ben Ze'ev \& R.G. Kenneth - Mycotaxon 10: 227. 1979; renamed Erynia erinacea (Ben Ze'ev \& R.G. Kenneth) Remaud. \& Hennebert - Ibidem 11: 302. 1980. Attacks the insects Aphis craccivora, A. umbrella, A. fabae and Myzus persicae. Israel. (Zy)

Zoophthora orientalis Ben Ze'ev \& R.G. Kenneth - Phytoparasitica 9: 35. 1981; renamed Erynia orientalis (Ben Ze'ev \& R.G. Kenneth) Humber, Ben Ze'ev \& R.G. Kenneth, in Humber and Ben Ze'ev - Mycotaxon 13: 509. 1981. Attacks the insect Aphis citricola. Israel. (Zy)

Ascomycetes: Caenothyrium citri Reichert \& Chorin - Phytopath. Mediterr. 4: 13. 1965. Induces a sooty blotch disease of Citrus plants. Israel. (As)

Chaetomium dreyfussii Arx, in Arx, Guarro \& Figueras - Beih. Nova Hedwigia 84: 6. 1986. Developed on hare dung incubated in a damp chamber. Israel. (As)

Chaetomium oblatum Dreyfuss \& Arx, in Arx, Guarro \& Figueras - Beih. Nova Hedwigia Heft 84: 6. 1986. Isolated from seeds of an unknown plant. Israel. (As)

Clavispora lusitaniae Rodr.-Mir. - Antonie van Leeuwenhoek 45(3): 480. 1979; type species of the heterothallic yeast genus Clavispora Rodr.-Mir. The anamorphic mating strains were isolated from Citrus peel juice and identified as Candida lusitaniae van Uden \& do Carmo Souza and C. obtuse (Dietrichson) van Uden \& do Carmo Souza. Israel. (As)

Gymnascella marismortui Buchalo, Nevo, Wasser, Oren \& Molitoris (as 'marismortuis') - Proc. R. Soc., Lond. , B. Biol. Sci. 265(1462): 1462. 1998; nom. invalid., Art. 37.5 ICBN. Gymnascella marismortuis Buchalo, Nevo, Wasser, Oren \& Molitoris: Specimen UHA No. 1632 selected as LECTOTYPE by Mouchacca (2004). Isolated from a water sample of the Dead Sea Lake. Israel. (As)

Leptosphaeria pimpinellae Lowen \& Sivan. - Mycotaxon 35(2): 205. 1989; now Plenodomus pimpinellae (Lowen \& Sivan.) Gruyter, Aveskamp \& Verkley, in Gruyter, Woudenberg, Aveskamp, Verkley, Groenewald \& Crous - Stud. Mycol., Utrecht 75: 22. 2012. Ana-morph: Phoma pimpinellae Boerema \& Gruyter - Persoonia 17: 278. 1999; nom. invalid. , Art. 37.5 ICBN; now Phoma pimpinellae Boerema \& Gruyter, in Boerema - Ibidem 18: 159. 2003; Specimen L 992.163-138, a dried culture on malt extract agar, was then selected by Boerema (2003) as LECTOTYPE. Developed on dead stems of Pimpinella anisa. Israel. (As)

Microascus desmosporus var. macroperithecia Sage, Steiman, Seigle-Mur. \& Guiraud Mycotaxon 55: 191. 1995; nom. invalid. , Art. 37.5 ICBN; now Microascus desmosporus (Lechmere) Curzi - Boll. R. Staz. Patolog. Veget. Roma, N.S. 11: 60. 1931. Isolated from a desert soil. Israel. (As)

Microascus dimonatus Sage, Steiman, Seigle-Mur. \& Guiraud - Mycotaxon 55: 189-201. 1995; nom. invalid. , Art. 37.5 ICBN. Isolated from a desert soil. Israel. (As)

Microascus trigonosporus var. macroperithecia Sage, Steiman, Seigle-Mur. \& Guiraud Ibidem 55: 194. 1995; nom. invalid. , Art. 37.5 ICBN; a superfluous distinction of Microascus trigonosporus C.W. Emmons \& B.O. Dodge - Mycologia 23(5): 317. 1931; anamorph 
Scopulariopsis trigonosporus C.W. Emmons \& B.O. Dodge - Ibidem 23(5): 317. 1931. Isolated from a desert soil. Israel. (As)

Pleospora gracilariae E.G. Simmons \& S. Schatz, in Simmons - Mem. N. Y. bot. Gdn. 49: 305. 1989; anamorph: Stemphylium gracilariae E.G. Simmons - Ibidem 49: 305. 1989. Isolated from the structures of an algae belonging to a species of Gracilaria. Israel. (As)

Polystigma amygdalinum P.F. Cannon - Mycol. Res. 100: 1416. 1996. A serious pathogen of almond trees in the Middle East. Israel. (As)

Pulvinula constellatio var. microspora Nemlich \& Aviz.-Hersh. - Israel J. Bot. 25: 4. 1976; nom. invalid. , Art. 37.1 ICBN; now Pulvinula convexella (P. Karst.) Pfister - Occ. Pap. Farlow Herb. Crypt. Bot. 9: 9. 1976. Developed on a rich sandy loam soil of the coastal plain. Israel. (As)

Saccobolus kerverni f. minor Rayss - Palestine J. Bot., Jerusalem Series 4: 73. 1947; nom. invalid. , Art. 36.1 ICBN; now Saccobolus glaber (Pers.) Lambotte - Mém. Soc. Roy. Sci. Liége, Série 2, 14: 284.1887 (1888). Developed on dungs of sheep and goat incubated in a damp chamber. Palestine. (As)

Sphaerulina serograpta var. calliprini Rayss (as 'calliprinos') - Palestine J. Bot., Jerusalem Series 4: 37-46. 1953; now Sphaerulina serograpta (Durieu \& Mont.) Sacc. - Syll. fung. (Abellini) 2: 187. 1883. Collected on living leaves of Quercus calliprinos. West Bank (Palestine). (As)

Thielavia terricola f. minor Rayss \& Borut - Mycopath. Mycol. Appl. 10(2): 160. 1958

[= T. terricola var. minor (Rayss \& Borut) C. Booth - Mycol. Pap. 83: 7. 1961; = T. minor (Rayss \& Borut) Malloch \& Cain - Mycologia 65(5): 1065. 1973)]. Now regarded as matching T. terricola (J.C. Gilman \& E.V. Abbott) C.W. Emmons - Bull. Torrey bot. Club 57: 124. 1930 (三 Coniothyrium terricola J.C. Gilman \& E.V. Abbott - Iowa State College Journal of Science 1(3): 267. 1927. Isolated from a sand dune. West Bank (Palestine). (As)

Basidiomycetes: Agaricus bonii Wasser - Docums Mycol. 25 (Nos. 98-100): 470. 1995. Collected on the ground under trees of Quercus calliprinos. Israel. (Ba)

Agaricus herinkii Wasser - Ceská Mykol. 48(4): 238. 1996. Collected under trees of Quercus calliprinos and Pinus halepensis. Israel. (Ba)

Agaricus meleagris var. fibrillosus Aviz.-Hersh. - Bull. Res. Counc. Israel, Sect. D, Botany 10: 174. 1961; nom. invalid. , Arts. 36.1 \& 37.1 ICBN; regarded as a superfluous variety of Agaricus meleagris With. - Bot. Arr. Brit. Plants, Edn. 2 (London) 3: 379. 1792. Developed amongst Stenotaphrum secundatum Israel. (Ba)

Agaricus nevoi Wasser - Docums Mycol. 25 (Nos. 98-100): 472. 1995. Developed on the ground under trees of Quercus calliprinos. Israel. (Ba)

Boletus reichertii Aviz.-Hersh. \& Binyam. - Trans. Br. Mycol. Soc. 59: 228. 1972. Collected under trees of Quercus calliprinos. Israel. (Ba)

Crepidotus variabilis var. stercorarius Reichert \& Aviz.-Hersh. - Bull. Res. Counc. Israël, Sect. D, Botany 7: 230. 1959; regarded as a superfluous distinction of the species Crepidotus variabilis (Pers.) P. Kumm. - Führ. Pilzk. (Zerbst): 74. 1871. Developed on horse dung incubated in a damp chamber. Israel. (Ba)

Entyloma ambrosiae-maritimae Rayss - Palestine J. Bot., Jerusalem Series 5: 230. 1952. Observed on living leaves of Ambrosia maritima. West Bank (Palestine). (Ba)

Entyloma parietariae Rayss - Ibidem 5: 230. 1952. Observed on living leaves of Parietaria judaica and P. alsinifolia. West Bank (Palestine). (Ba)

Entyloma taraxaci Vánky - Mycotaxon 18: 322. 1983. On living leaves of Taraxacum megalorrhizon. Israel. (Ba)

Lepista sordida var. gracilis Reichert \& Aviz.-Hersh. - Bull. Res. Counc. Israel, Sect. D, Botany 7: 230. 1959; nom. invalid., Art. 37.1 ICBN, and a superfluous distinction of the species 
Lepista sordida (Schumach.) Singer - Lilloa 22: 193. 1949 (1951). On the soil surface under Acacia trees. Israel. (Ba)

Macowanites galileënsis M.M. Moser, Binjam. \& Aviz.-Hersh. - Trans. Br. Mycol. Soc. 68: 371. 1977. Observed on the ground under Quercus calliprinos. Israel. (Ba)

Puccinia crucianellae var. crucianellae-macrostachyae Petr. - Sydowia 11: 313. 1957 (published 30.VI.1958). On living leaves of Crucianella macrostachya. Israel. (Ba) Puccinia rimosa f. nattrassi Rayss, in Guyot (as 'natrassii') - Uredineana 3: 181. 1951; nom. invalid. , Art. 36.1 ICBN. On living leaves of Juncus maritimus. Israel. (Ba)

Russula carmelensis M.M. Moser, Binyam. \& Aviz.-Hersh. - Trans. Br. Mycol. Soc. 68: 376. 1977. Observed on soil under trees of Quercus calliprinos. Israel. (Ba)

Scleroderma multiloculare Dring \& Rayss - Israël J. Bot. 12: 158. 1963 (964). On the soil surface under Eucalyptus trees. Israel. (Ba)

Tricholoma weizianum Reichert \& Aviz.-Hersh. - Bull. Res. Coun. Israël, Sect. D, Botany 7: 231. 1959; nom. invalid. , Art. 37.1 ICBN. Collected on the ground under Pinus halepensis. Israel. (Ba)

Uromyces anthyllidis f. trigonellae Rayss, in Guyot - Uredineana 3: 193. 1951. On living leaves of Trigonella arabica, T. berythea and T. stellata. Israel. (Ba)

Uromyces christensenii J. Anikster \& I. Wahl - Israël J. Bot. 15: 98. 1966. Developed on living leaves of Muscari parviflorum. Israel. (Ba)

Uromyces oliveirae J. Anikster \& I. Wahl - Bull. Trimest. Soc. Mycol. Fr. 82: 556. 1966. On living leaves of Bellevalia eiglii. Israel. (Ba)

Uromyces poae f. sp. asiatici-hackelii Rayss \& Chab.-Frydm., in Guyot - Uredineana 5: 6. 1958. Collected on living leaves of Poa hackelii. West Bank (Palestine). (Ba)

Uromyces rayssii J. Anikster \& I. Wahl - Bull. trimest. Soc. Mycol. Fr. 82(4): 552. 1966 [1967]. On living leaves of Scilla hyacinthoides. Israel. (Ba)

Uromyces reichertii J. Anikster \& I. Wahl - Ibidem 82: 548. 1966. Colonizing living leaves of Scilla hyacinthoides. Israel. (Ba)

Uromyces scillarum f. sp. pancratii J. Anikster - Trans. Br. Mycol. Soc. 89: 330. 1987. On living leaves of Pancratium parviflorum. Israel. (Ba)

Uromyces viennot-bourginii J. Anikster \& I. Wahl - Bull. Trimest. Soc. Mycol. Fr. 82: 554. 1966. On living leaves of Hordeum vulgare. Israel. (Ba)

Ustilago jehudana Zundel - Mycologia 36: 401. 1944; present name Haradaea jehudana (Zundel) Denchev \& H.D. Shin, in Denchev, Moore \& Shin - Mycol. Balcanica 3(1): 72. 2006. On inflorescences of Silene apetala. Palestine. (Ba)

Mitosporic Fungi: Alternaria dumosa E.G. Simmons - Mycotaxon 70: 310. 1999. Isolated from leaf lesions of Minneola tangelo Citrus trees. Israel. (Mi)

Alternaria interrupta E.G. Simmons - Ibidem 70: 306. 1999. Induces leaf lesions of Minneola tangelo Citrus trees. Israel. (Mi)

Aspergillus homomorphus Steiman, Guiraud, Sage \& Seigle-Mur. - Syst. Appl. Microbiol. 17: 621. 1995; nom. invalid., Art. 37.4 ICBN; validated as Aspergillus homomorphus Steiman, Guiraud, Sage \& Seigle-Mur. ex Samson \& Frisvad, in Samson, Houbraken, Kuijpers, Frank \& Frisvad - Stud. Mycol., Utrecht 50(1): 58. 2004. Isolated from a desert soil. Israel. (Mi)

Aspergillus pseudoheteromorphus Steiman, Guiraud, Sage \& Seigle-Mur. - Syst. Appl. Microbiol. 17(4): 622. 1995; nom. invalid., Art. 40.4 (Melbourne). Isolated from a desert soil. Israel. (Mi)

Bipolaris israeli Steiman, Guiraud, Seigle-Mur. \& Sage (as 'israelii') - Ibidem 19: 183. 1996. Isolated from a saline desert soil. Israel. (Mi)

Cercospora cephalariae Rayss - Palestine J. Bot., Jerusalem Series 5: 24. 1950. On living leaves of Cephalaria joppica. West Bank (Palestine). (Mi) 
Cercospora judaica Rayss - Ibidem 5: 41. 1943; a present synonym of Passalora dissiliens (Duby) U. Braun \& Crous - Mycosphaerella and its anamorphs: 1. Names published in Cercospora and Passalora, CBS Utrecht: 164. 2003 (三 Torula dissiliens Duby - Mém. Soc. Phys. Genève 7: 128. 1835). On living leaves of Vitis vinifera. Palestine. (Mi)

Cercospora rhagadioli var. palaestinae Rayss - Bull. Res. Coun. Israel, Sect. D, Bot. 5: 45. 1955. Observed on living leaves of Rhagadiolus stellatus. West Bank (Palestine). (Mi)

Cercosporina hierosolymitana Rayss - Ibidem 5: 45. 1955. Colonising living leaves of Salvia hierosolymitana. West Bank (Palestine). (Mi)

Cytosporina crataegi f. obesispora Rayss - Palestine J. Bot., Jersusalem Series 3: 26. 1943; nom. invalid., Art. 36.1 ICBN; a superfluous distinction of the species Cytosporina crataegi Allesch. - Rabenhorst Krypt.-Fl., Edn. 2 (Leipzig) 1(6): 950.1899 (1900). Developed on twigs of Crataegus azarolus. Palestine. (Mi)

Diplodia pinea f. sp. cupressi Solel, Madar, Kimchi \& Golan - Can. J. Pl. Path. 9: 117. 1987. Isolated from diseased cambial tissue of Cupressus sempervirens var. stricta and $C$. sempervirens var. horizontalis. Israel. (Mi)

Exserohilum israelii Steiman, Guiraud, Seigle-Mur. \& Sage (as 'israeli') - Antonie van Leeuwenhoek 78(2): 155. 2000. Isolated from a desert soil. Israel. (Mi)

Exserohilum sodomii Guiraud, Steiman, Seigle-Mur. \& Sage - Ibidem 72(4): 318. 1997. Isolated from a desert soil. Israel. (Mi)

Fusariella hughesii Chab.-Frydm. - Can. J. Bot. 42(11): 1485. 1964. Living strains isolated from seeds of Trigonella Arabica and Phalaris minor. Israel. (Mi)

Fusarium oxysporum f. sp. heliotropii Netzer \& Weintal (as 'heliotropae') Phytoparasitica 15: 140. 1987. Isolated from wilted plants of the common weed Heliotropium europaeum. Israel. (Mi)

Oidium arachidis Chorin - Bull. Res. Coun. Israël, Sect. D, Botany 10(1-4): 148. 1961. Developed on living leaves of Arachis hypogaea. Israel. (Mi)

Oidium matthiolae Rayss 'sp. nov. ad interim' - Palestine J. Bot., Jersusalem Series 1: 325. 1940; nom. invalid. , Art. 34.1b ICBN; no further information about this binomial could be traced. Developed on living leaves of cultivated Matthiola incana. Palestine. (Mi)

Penicillium discolor Frisvad \& Samson, in Frisvad, Samson, Rassing, Horst, Rijn \& Stark - Antonie van Leeuwenhoek 72: 120. 1997. Isolated from moulded Raphanus sativus. Israel. (Mi)

Penicillium italicum var. avellaneum Samson \& Gutter, in Samson, Stolk \& Hadlock Stud. Mycol., Baarn 11: 30. 1976; a synonym of P. italicum Wehmer - Hedwigia 33: 211. 1894. Isolated from a decaying Citrus fruit. Israel. (Mi)

Periconia pycnospora f. israelitica Rayss \& Borut - Mycopath. Mycol. Appl. 10(2): 167. 1958; nom. invalid. , Art. 37.1 ICBN, and represents a strain of Periconia byssoides Pers. - Syn. meth. fung. (Göttingen) 1: 18. 1801 (= Pericona pycnospora Fresen. - Beitr. Mykol. 1: 20. 1850). Isolated from a loess soil. West Bank (Palestine). (Mi)

Phyllosticta fusiformis f. microcarpa Rayss - Palestine J. Bot., Jerusalem Series 3: 24. 1943; nom. invalid. , Art. 36.1 ICBN; and a superfluous distinction of the species $P$. fusiformis N. Aggéry \& Aggéry - Revue de Pathologie Végétale et d'Entom. Agric. de France 15: 103. 1928. Developed on living leaves of Eriobotrya japonica. Palestine. (Mi)

Pseudomicrodochium fusarioides B. Sutton \& C.K. Campb., in Sutton, Campbell \& Goldschmied-Reouven - Mycopathologia 114: 160. 1991; now Cyphellophora fusarioides (B. Sutton \& C.K. Campb.) Decock, in Decock, Delgado-Rodriguez, Buchet \& Seng - Antonie van Leeuwenhoek 84(3): 213. 2003. Isolated from bronchial lavage fluid from Homo sapiens. Israel. (Mi)

Septoria erodii Rayss - Palestine J. Bot., Jerusalem Series, 5: 18. 1950. Developed on living leaves of Erodium malacoides. West Bank (Palestine). (Mi) 
Septoria koeleriae var. macrocarpa Rayss - Ibidem 3: 31. 1943; a superfluous distinction of the species Septora koeleriae Cocc. \& Morini - Mém. R. Accad. Sci. Ist. Bologna, Ser. 4, 5: no. 176. 1883. Developed on living leaves of Koeleria phleoides. Palestine. (Mi)

Septoria urticae-piluliferae Rayss - Palestine J. Bot., Jerusalem Series 3: 22-51. 1943. Developed on living leaves of Urtica pilulifera. Palestine. (Mi)

Septoria withaniae Rayss - Bull. Res. Council Israël, Sect. D, 5: 39. 1955. Developed on living leaves of Withania somnifera. West Bank. (Palestine). (Mi)

Stemphylium botryosum f. sp. lycopersici Rotem, Y. Cohen \& I. Wahl - Canad. J. Plant Sci. 46(3): 270. 1966; nom. invalid. , Art. 39.1 (Melbourne) and a superfluous subspecific distinction of Stemphylium herbarum E.G. Simmons - Sydowia 38: 291. 1985. Developed on living leaves of Lycopersicon esculentum. Israel. (Mi)

Agonomycetes: Sclerotium bataticola subsp. bataticola Reichert \& Hellinger - Palestine J. Bot., Rehovot Series 6: 137. 1947; nom. invalid. , Art. 32.1; see Art. 24.3 (Melbourne). A superfluous distinction of Rhizoctonia bataticola (Taubenh.) E.J. Butler, in Briton-Jones - Bull. Minist. Agric., Egypt, Bot. Section 49: 65. 1925 [三 Sclerotium bataticola Taubenh. - Phytopathology 3(3): 164. 1913]. Isolated from infected bean and cotton plants. Palestine. (Ag)

Sclerotium bataticola subsp. intermedia Reichert \& Hellinger (as 'intermedium') - Ibidem 6: 138. 1947; nom. invalid., Art. 32.1; see Art. 24.3 (Melbourne). A synonym of Rhizoctonia bataticola (Taubenh.) E.J. Butler, in Briton-Jones - Bull. Minist. Agric., Egypt, Bot. Section 49: 65. 1925 [三 Sclerotium bataticola Taubenh. - Phytopathology 3: 161. 1913]. Isolated from infected cotton and tobacco plants. Palestine. (Ag)

Sclerotium bataticola subsp. sesamica Reichert \& Hellinger (as 'sesamicum') - Ibidem 6: 138. 1947; nom. invalid., Art. 32.1; see Art. 24.3 (Melbourne). A synonym of Rhizoctonia bataticola (Taubenh.) E.J. Butler, in Briton-Jones - Bull. Minist. Agric., Egypt, Bot. Section 49: 65. 1925 [三 Sclerotium bataticola Taubenh. - Phytopathology 3: 161. 1913]. Isolated from infected sesame plants. Palestine. (Ag)

Sclerotium bataticola subsp. typical Reichert \& Hellinger (as 'typicum') - Ibidem 6: 137. 1947; nom. invalid. , Art. 32.1; see Art. 24.3 (Melbourne); a synonym of Rhizoctonia bataticola (Taubenh.) E.J. Butler, in Briton-Jones - Bull. Min. Agric., Egypt, Bot. Section 49: 65. 1925 [三 Sclerotium bataticola Taubenh. - Phytopathology 3: 161. 1913]. Isolated from infected sesame plants. Palestine. (Ag)

\section{SAUDI ARABIA}

Mitosporic Fungi: Alternaria selini E.G. Simmons - Mycotaxon 55: 109. 1995. Developed on living leaves of Petroselinum crispum. Saudi Arabia. (Mi)

Cercospora saudii Mohammed (as 'saudiaii'), in Mohammed, Al-Namlah \& Vaughan Indian J. Bot. 10: 149-151. 1988. Observed on living leaves of Carissa grandiflora. Saudi Arabia. (Mi)

Monodictys saudii M.I. Ali, in M.I. Ali \& A.N. Abou-Heilah - Journal of the College of Science, King Saud University 14(2): 295. 1983; nom. invalid., Arts. 36.1 \& 37.1 ICBN. Isolated from a saline soil. Saudi Arabia. (Mi)

Ramichloridium mackenziei C.K. Campb. \& Al-Hedaithy - J. Med. Vet. Mycol. 31(4): 330. 1993; later on renamed Rhinocladiella mackenziei (C.K. Campb. \& Al-Hedaithy) Arzanlou \& Crous, in Arzanlou, Groenwald, Gams, Braun, Shin \& Crous - Stud. Myco. , Baarn 58: 80. 2007. Isolated from a 55-years old Saudi female suffering from brain abscesses. Saudi Arabia. (Mi) 


\section{The SUDAN}

Ascomycetes: Astrocystis hughesii Læssøe \& Spooner - Kew Bull. 49: 16. 1994. Developed on culms of an unknown stout grass. The Sudan. (As)

Chaetosphaeria anglica P.J. Fisher \& O. Petrini - Trans. Br. Mycol. Soc. 81: 396. 1983. Developed on decomposing wood collected on the Blue Nile River bank. The Sudan. (As)

Cochliobolus cymbopogonis J.A. Hall \& Sivan. - Ibidem 59(2): 315. 1972; anamorph: Curvularia cymbopogonis (C.W. Dodge) J.W. Groves \& Skolko [as 'cymbopogi'] - Canadian Journal of Research, Section C 23: 96. 1945. Isolated from Sorghum seeds. The Sudan. (As)

Meliola sudanensis Hansf. - Sydowia 10(1-6): 91. 1957. Developed on leaves of Combretum sp. The Sudan. (As)

Plagiosphaera nilotica M. Monod \& P.J. Fisher - Ibidem 81: 177. 1983. Developed on dead twigs immerged in the Nile River. The Sudan. (As)

Pseudophaeotrichum sudanense Aue, E. Müll. \& C. Stoll - Nova Hedwigia 17(1-4): 84. 1969; type species of the genus Pseudophaeotrichum Aue, E. Müll. \& C. Stoll. The relevant synonymy with Neotestudina rosatii Segretain \& Destombes - C. r. hebd. Séanc. Acad. Sci., Paris 253: 2579. 1961, is presently questioned [see Hawksworth, D. L. 1979. Ascospore sculpturing and generic concepts in the Testudinaceae (syn. Zopfiaceae) - Can. J. Bot. 57: 9199]. Isolated from soil. The Sudan. (As)

Setosphaeria khartoumensis El Shafie \& J. Webster - Trans. Br. Mycol. Soc. 77(2): 442. 1981; anamorph Exserohilum khartoumensis (El Shafie \& J. Webster) P.M. Kirk - Index Fungorum 269: 1. 2015. Isolated from grains of Sorghum bicolor var. majo. The Sudan. (As)

Stigmatomyces ligabuei W. Rossi - Boll. Mus. Civ. Stor. Nat. Venezia 35: 163. 1984 (1986). Infecting the fly insect Tinophilus indigenus. The Sudan. (As)

Basidiomycetes: Phakopsora setariae G.B. Cummins - Bull. Torrey Bot. Club 83: 223. 1956. On living leaves of Setaria lancea. The Sudan. (Ba)

Sphacelotheca suddiana Spooner - Kew Bull. 39: 463. 1984; present name Ustilago suddiana (Spooner) Vánky - Mycotaxon 81: 426. 2002. Collected on panicles of Suddia sagittifolia. The Sudan. (Ba)

Sporisorium eriochloae Vánky - Mycotaxon 74: 174. 2000; renamed Anthracocystis eriochloae (Vanky) McTaggart \& R.G. Shivas, in McTaggart, Shivas, Geering, Vanky \& Scharaschkin - Persoonia, Molecular Phylogeny and Evolution of Fungi 29: 122. 2012. Developed in inflorescences of Eriochloa fatmensis. The Sudan. (Ba)

Sorosporium urelytri L. Ling - Sydowia 7: 156. 1953; recently redisposed as Anthracocystis urelytri (L. Ling) T. Denchev \& Denchev, in Teodor T. Denchev \& Cvetomir M. Denchev - Phytotaxa 253: 229. 2016. Developed on Urelytrium giganteum. The Sudan. (Ba)

Uromyces hypoëstis Tarr \& G.F. Laundon, in Laundon - Mycol. Pap. 89: 81. 1963 (三 Trichobasis hypoëstis Cooke - Grevillea 10: 128. 1882; a generic change due to a misinterpreation of the rust stage). On living leaves of Hypoestis verticillaris. The Sudan. (Ba)

Mitosporic Fungi: Cercospora tarrii Deighton - Mycol. Pap. 71: 16. 1959. Observed on living leaves of Phyllanthus maderaspatensis. The Sudan. (Mi)

Drechslera gedarefensis El Shafie - Trans. Br. Mycol. Soc. 74(2): 437. 1980; renamed Exserohilum gedarefense (El Shafie) Alcorn [as 'gedarefensis'] - Mycotaxon 17: 68. 1983. Isolated from infected grains of Sorghum bicolor. The Sudan. (Mi)

Mycovellosiella tarrii Deighton - Mycol. Pap. 137: 20. 1974; now Passalora tarrii (Deighton) U. Braun \& Crous, in Crous \& Braun - Mycosphaerella and its anamorphs: 1. Names published in Cercospora and Passalora, CBS Diversity Ser. (Utrecht) 1: 397. 2003. Developed on living leaves of Solanum melongena. The Sudan. (Mi) 
Phaeoramularia sudanensis Deighton - Ibidem 144: 45. 1979; now Passalora sudanensis (Deighton) U. Braun \& Crous, in Crous \& Braun - Mycosphaerella and its anamorphs: 1. Names published in Cercospora and Passalora, CBS Diversity Series (Utrecht) 1: 471. 2003. Developed on living leaves of Clematis sp. The Sudan. (Mi)

Stigmina beshirii M.B. Ellis - Ibidem 72: 38. 1959; now Scolecostigmina beshirii (M. B. Ellis) U. Braun - Schlechtendalia 3: 34.1999 [三 Sciniatosporium beshirii (M.B. Ellis) MorganJones - Can J. Bot. 49(6): 995. 1971. Developed on living leaves of Allophylus sp. The Sudan. (Mi)

Stigmina sudanensis M.B. Ellis - Ibidem 72: 47. 1959; now Scolecostigmina sudanensis (M.B. Ellis) U. Braun - Schlechtendalia 3: 40.1999 [三 Sciniatosporium sudanense (M.B. Ellis) Morgan-Jones - Can. J. Bot. 49(6): 1005. 1971]. Developed on leaves of Ficus sp. The Sudan. (Mi)

\section{SYRIA}

Ascomycetes: Erysiphe communis f. fibigiae Rayss - Bull. Trimest. Soc. Mycol. France 62: 11. 1946; a synonym of Erysiphe cruciferarum J. Opiz ex L. Junell - Svensk Bot. Tidsk. 61: 217. 1967 [see Braun U., 1995 - The Powdery Mildews (Erysiphales) of Europe. Jena, Germany: Gustav Fischer Verlag]. Developed on silicules of Fibigia clypeata. Syria. (As)

Guignardia euphorbiae Rayss - Ibidem 62: 20. 1946; non Guignardia euphorbiae T.M. Achundov - Izv. Akad. Nauk azerb. SSR, Ser. Biol. Nauk: 5. 1971, nom. illegit. , Art. 53.1. Developed on dead branches of Euphorbia erinacea. Syria. (As)

Basidiomycetes: Tilletia sphenopodis Rayss (as 'sphenopi') - Ibidem 62(3): 25. 1946. Developed in ovaries of Sphenopus divaricatus. Syria. (Ba)

Mitosporic Fungi: Aspergillus kassunensis Baghd. - Nov. sist. Niz. Rast., 1968: 113. 1968; a present synonym of Aspergillus subsessilis Raper \& Fennell - The Genus Aspergillus: 530. 1965. Isolated from an arid soil. Syria. (Mi)

Penicillium arabicum Baghd. - Ibidem 1968, 5: 105. 1968; a synonym of $P$. decumbens Thom - Bull. U.S. Department of Agriculture, Bureau Animal Industry, 118: 71. 1910. Isolated from a cultivated soil. Syria. (Mi)

Penicillium baradicum Baghd. - Ibidem 1968, 5: 107. 1968; a synonym of P. citrinum Thom - Bull. U.S. Department of Agriculture, Bureau Animal Industry 118: 61. 1910. Isolated from a cultivated soil. Syria. (Mi)

Penicillium damascenum Baghd. - Ibidem 1968 5: 101. 1968; a synonym of P. melinii Thom - The Penicillia: 273. 1930. Isolated from a cultivated soil. Syria. (Mi)

Penicillium eben-bitarianum Baghd. - Ibidem 5: 106. 1968; reported as a synonym of $P$. dierckxii Biourge - La Cellule 33: 133. 1923. Isolated from a cultivated soil. Syria. (Mi)

Penicillium es-suveidense Baghd. - Ibidem 5: 108. 1968. Isolated from a cultivated soil. Syria. (Mi)

Penicillium gorlenkoanum Baghd. - Ibidem 5: 97. 1968; a synonym of P. restrictum J.C. Gilman \& E.V. Abbott - Journal of Iowa State College, Science 1: 297. 1927. From a cultivated soil. Syria. (Mi)

Penicillium harmonense Baghd. - Ibidem 5: 102. 1968. Isolated from a cultivated soil. Syria. (Mi)

Penicillium kabunicum Baghd. - Ibidem 5: 98. 1968; now a synonym of P. simplicissimum (Oudem.) Thom - The Penicillia: 335. 1930. Isolated from a cultivated soil. Syria. (Mi)

Penicillium quercetorum Baghd. - Ibidem 5: 110. 1968. Isolated from a cultivated soil. Syria. (Mi) 
Penicillium sizovae Baghd. - Ibidem 5: 103. 1968; a present synonym of P. dierckxii Biourge - La Cellule 33(1): 313. 1923. Isolated from a cultivated soil. Syria. (Mi)

Penicillium syriacum Baghd. - Ibidem 5: 103. 1968; a synonym of P. miczynskii K.M. Zaleski - Bull. Acad. Pol. Sci., Math. et Nat., Sér. B: 482. 1927. Isolated from a cultivated soil. Syria. (Mi)

Penicillium yarmokense Baghd. - Ibidem 5: 96-114. 1968; a synonym of P. canescens Sopp - Monograph of Penicillium 11: 181. 1912. Isolated from a cultivated soil. Syria. (Mi)

\section{SOME RECENT TITLES on the Biodiversity of Fungi in the Middle East}

\section{Regional Titles}

Mouchacca J. 2008. Novel fungal taxa from the arid Middle East introduced prior to the year 1940. I - Non lichenized Ascomycetes. Cryptog. Mycol. 29(4): 365-388.

Mouchacca J. 2009. Novel fungal taxa from the arid Middle East introduced prior to the year 1940. II - Anamorphic fungi: Hyphomycetes. Cryptog. Mycol. 30(2): 199-222.

Mouchacca J. 2009 b. Novel fungal taxa from the arid Middle East introduced prior to the year 1940. III - Anamorphic fungi: Coelomycetes. Cryptog. Mycol. 30(4): 377-403.

\section{State Restricted Titles}

\section{E G Y P T}

Abdel-Azeem A.M. 2009. Operation Wallacea in Egyt. I - A preliminary study on diversity of fungi in the world heritage site of Saint Katherine, Egypt. Assiut Univ. J. Bot. 38(1): 2954.

Abdel-Azeem A.M. 2010. The history, fungal biodiversity, conservation, and future perspectives for mycology in Egypt. IMA Fungus 1(2): 123-142.

Abdel-Azeem A.M. and Salem F.M., 2013. A checklist of Egyptian fungi. I. Protozoan fungal analogues. Mycosphere 4(4): 794-807.

Abdel-Azeem A.M. and Salem F.M., 2015. Fungi fimicola Aegyptiaci: I. Recent investigations and conservation in arid South Sinai. Mycosphere 6(2), 174-194.

Abd-El-Moneim T.S. and Abdel-Azeem A.M. 2009. Operation Wallacea in Egypt. II. Diversity of arbuscular mycorrhizal fungi in different elevation wadis in Saint Katherine protectorate, Egypt. Assiut Univ. J. Bot. 38(1): 55-74.

AUMC 2010. Assiut University Mycological Center. Catalogue of Culture Collection (2 ${ }^{\text {nd }}$ Edition).

Moubasher A.H., Abdel-Sater A.M. and Zeinab S. 2016. Biodiversity and molecular characterisation of yeast and filamentous fungi in the air of citrus and grapevine plantations in Assiut area, Egypt. Mycosphere 7(3): 236-261.

Moubasher A.H., Moharram A.M. and Ismail M.A. 2011. Mycobiota of Egypt II - The genus Aspergillus and its teleomorphs. Assiut University Mycological Centre, Assiut, Egypt, AUMC Descriptions 2: 1-35.

Moustafa A.F. 2006. Fungi of Egypt. I. Zygomycetes. Assiut University Mycological Centre, Assiut, Egypt, AUMC Descriptions 1: 1-34.

Moustafa A.F. and Abdel-Azeem A.M. 2005. The Genus Chaetomium in Egypt. El-Minia Science Bulletin 16(2): 235-256.

Moustafa A.F. and Abdel-Azeem A.M. 2006. Some new records to the Egyptian Ascomycetes with a provisional key to their identification. Assiut Univ. J. Bot. 35(1): 87-103.

Moustafa A.F. and Abdel-Azeem A.M. 2011. An annotated check-list of Ascomycetes reported from soil and other terricolous substrates in Egypt. J. Bas. Appl. Mycol. 2: 1-27.

Seaward M.R.D. and Sipman H.J.M. 2006. An updated checklist of lichenized and lichenicolous fungi for Egypt. Willdenowia 36 (Special Issue): 537-555. 
Shimaa R.H. 2016. Diversity of Aspergillus and Penicillium of Farmland in Egypt. International Journal of Innovative Studies in Sciences and Engineering Technology (IJISSET) 2(5): 710.

Zohri A.A., Elkhateeb W.A., Mazen M.B., Hashem M. and Daba G.M. 2014. Study of soil mycobiota diversity in some new reclaimed areas, Egypt. Egyptian Pharmaceutical Journal 13: 58-63.

Soliman, E.A., Abdel-Azeem, A.M., Salem, F.M., Nafady, N.A, Mehesien, M.T., Ahmed, A.I.S., Mohsen, E.I., Abdel-Azeem, M.A. and Hassan, S.S. 2016. A taxonomic analysis of miscellaneous fungi collected and described from Egypt till 1931. Studies in Fungi 1(1): 11-33.

\section{R A Q}

Abdullah S.K. and Atroshi H.I.M. 2014. New records of fungi on wheat grains from Iraq. Journal of the University of Zakho 2A: 37-46.

Abdullah S.K. and Azzo N.M. 2015. Two new records of Chaetomium species isolated from soil under Grapevine Plantations and a Checklist of the Genus in Iraq. Journal of Agricultural Technology 11(7): 1515-1522.

Abdullah S.K. and Saadullah A.A. 2013. Soil mycobiota at grapevine plantations in Duhok, North Iraq. Mesopotamia journal of Agriculture 41 (Suppl. 1): 438-448.

Al-Saadoon A.H. 2000. Additions to Podospora of Iraq. Basrah Journal of Science 18: 27-38.

Al-Saadoon A.H. and Al-Dossary M.N. 2014. Fungi from submerged plant debris in aquatic habitats in Iraq. Int. J. Biodiv. Conser. 6(6): 465-487.

Toma F.M., Ismael H.M. and Faqi A.F.Q. 2013. Survey and identification of mushrooms in Erbil Governorate. Research Journal of Environmental and Earth Sciences 5(5): 262-266.

\section{S R A E L}

Barseghyan G.S. and Wasser S.P. 2010. Species diversity of Hypogeous Ascomycetes in Israel. Mycobiology 38(3): 159-165.

Savchenko K.G., Heluta V.P., Wasser S.P. and Nevo E. 2014. Rust fungi (Pucciniales) of Israel. II. The genus Uromyces. Nova Hedwigia 98(3-4): 393-407.

Savchenko K.G., Heluta V.P., Wasser S.P. and Nevo E. 2014. Rust fungi (Pucciniales) of Israel. III. The genus Puccinia. Nova Hedwigia 99(1-2): 27-47.

Savchenko K.G., Wasser S.P., Heluta V.P. and Nevo E. 2015. Smut Fungi of Israel. Ed. by Paul A. Volz (Biodiversity of Cyanoprokaryotes, Algae and Fungi of Israel), $160 \mathrm{pp}$.

Temina M., Kondratyuk S.Ya., Zelenko S., Nevo E. and Wasser S.P. 2005. Lichen-Forming, Lichenicolous, and Allied Fungi of Israel. A.R.A. Gantner Verlag K.-G., Ruggell, 385 pp.

Tura D., Zmitrovich I.V., Wasser S.P. and Nevo E., 2010. Check-list of Hymenomycetes (Aphyllophorales s.1.) and Heterobasidiomycetes in Israel. Mycobiology 38(4): 256-273.

Tura D., Zmitrovich I.V., Wasser S.P., Spirin W.A. and Nero E., 2011. Biodiversity of the Heterobasidiomycetes and Non-Gilled Hymenomycetes (former Aphyllophorales) of Israel. S.P. Wasser Ed. (Biodiveristy of Cyanoprocaryotes, Algae and Fungi of Israel). V. Ruggell A.R.A. Gantner Verlag K.-G., 547 pp.

\section{J O R D A N}

Abu-Dieyeh M.H., Barham R., Abu-Elteen K., Al-Rashidi R. and Shaheen I. 2010. Seasonal variation of fungal spores populations in the atmosphere of Zarqa area, Jordan. Aerobiologia 26(4): 263-276. 
Jaber B.M., Al-Silawi R. and Al-Najjar T. 2012. Isolation and molecular identification of Ascomycetes in sediments and waters of the Gulf of Aqaba, Red Sea. Natural Science 4(8): 555-561.

\section{K U W A I T}

Al-Musallam A.A.S., Al-Sammar H.F. and Al-Sané N.A. 2011. Diversity and dominance of fungi inhabiting the sabkha area in Kuwait. Botanica Marina 54: 83-94.

\section{LYBIA}

El-Said A.H.M., Sohair T.H. and El-Hadi A.G. 2009. Fungi associated with hairs of goat and sheep in Libya. Mycobiology 37(2): 82-88.

\section{O M A N}

El-Shafie A.E., Al-Mueini R., Al-Bahry S.N., Akindi A.Y., Mahmoud I.Y. and Al-Rawahi S.H. 2006. Nematophagous and non-nematophagous fungi belonging to the genera Arthrobotrys and Dactylella from soils of Oman. Kuwait J. Sci. Engin. 32: 57-72.

Sageewa S.N. Maharachchikumbura, Abdullah M. Al-Sadi, Moza Al-Kharousi, Nadeeya AlSaadi and Kevin D. Hyde. A checklist of fungi in Oman. Phytotaxa Vol. 273, No. 4: 12, Sept-ember 2016, ISSN 1179-3155 (print), ISSN 1179-3163 (online), Published by Magnolia Press, Auckland, New Zealand.

\section{SAUDI ARABIA}

Abdel-Wahab M.A., Hodhod M.S., Bahkali A.H.A. and Gareth Jones E.B. 2014. Marine Fungi of Saudi Arabia. Botanica Marina 57(4): 323-335.

Abou-Zeid A.M. and Altalhi A.E. 2006. Survey of some mushrooms in Al-Taif governorate of Saudi Arabia. World J. Agric. Science 2(1): 1-5.

Bawakedji A., Gargano M.L., Saitta A. and Benturella G. 2013. A new record of the desert truffle Picoa lefebvrei in Saudi Arabai. Mycotaxon 122(1): 243-247.

Mahmoud A.M., Al-Othman M.R., Abd El-Aziz A. 2013. Mycotoxigenic fungi contaminating corn and sorghum grains in Saudi Arabia. Pakistan J. Bot. 45(5): 1831-1839.

\section{S Y R I A}

Almanoufi A., Jamal M., Lillo de E., Tarasco E. and Yaseen T. 2012. A survey of the native entomopathogenic nematodes and fungi in the soil of southern region of Syria. Jordan Jour. Agric. Sciences 8(3): 358-366.

Volker J., Seaward M.R.D., Sipman H.J.M. and Zedda L. 2004. Lichens and lichenicolous fungi of Syria including a first checklist. Herzogia 17: 157-177.

\section{YEMEN}

Abdel-Sater M.A., Al-Zubeiry A.H. and Badah K.A. 2012. Microbiota associated with human eye infections in Taïz city, Yemen. J. Basic Appl. Mycol. 3: 1-11. 